\title{
UM ESTUDO SÔBRE A EOSINOFILIA NAS HELMINTOSES
}

\author{
Ruy Gomes de Moraes*
}

1 - Foram examinadas as fezes de 2.666 individuos, operários e funcionários de duas Emprêsas industriais, situadas, uma na cidade do Rio de Janeiro e outra no Estado do Rio (Brasil);

2 - Dos 2.666 indivíduos, $1941(72.80 \%)$ estavam parasitados por um ou mais helmintos e $725(27,20 \%)$ tinham seus exames de fezes negativos;

3 - De cada um dos 2.666 individuos foi feito um hemograma completo, tendo sido aproveitada a taxa de eosinófilos que, em associação com os exames de fezes, constituiu o objeto principal dêste trabalho.

4 - Na Tabela A observa-se o número de vêzes em que cada um dos vermes foi observado e seus respectivos percentuais. Embora não seja um trabalho de epidemiologia, verifica-se que $46,81 \%$ são infestados pelo Trichuris trichiura; $23,85 \%$ pelo Strongyloides stercoralis; $22,46 \%$ pelo $\mathrm{Ne}$ cator americanus $e /$ ou Ancylostoma duodenale; 20,51\% pelo Ascaris lumbricóides; $1,65 \%$ pelo Schistosoma mansoni; $0.67 \%$ pelo Enterobius vermicularis; $0,26 \%$ por Taenia solium ou $\mathrm{T}$. saginata $e 0,11 \%$ por Hymenolepis nana;

5 - Os exames de fezes foram feitos pelos métodos de Faust (ou de Ritchie), de Willis, de Baermann $e$ de sedimentação;

6 - A eosinofilia anotada foi a relativa ou em seu percentual, sendo considerada hipereosinofilia uma taxa, de eosinófilos igual ou superior a $\mathbf{5 \%}$ (Eo $>5 \%)$;

7 - Foram abordados de modo conciso os fatôres que provocam oscilações na eosinofilia normal tais como a idade, a raça, as horas do nictêmero, os fatôres físicos, o sexo, os fatôres quimicos e outros;

8 - Tratou-se de modo mais extenso das diferenças entre as hipereosinofilias parasitárias e não parasitárias, tendo sido focalizada a dinâmica da eosinofilia traduzida na curva de Lavier.

9 - A distribuição dos 2.666 casos foi feita pelos diferentes graus de eosinofilia, tendo sido levantados gráficos e traçadas curvas sôbre a distribuição de cada helminto $e$ de suas associações.

10 - Por ser necessário à explanação do assunto, foi criado o "índice eosinofílico", o qual corresponde à relaçâo entre o número de casos de um determinado grupo com Eo $>5 \%$ e Eo $<5 \%$. Para o total de casos positivos, ao "indice eosinofilico" denominamos "indice eosinofílico médio" e para o total dos negativos "índice eosinofílico residual";

11 - Estabelecendo-se o "indice eosinofilico", pode-se ajuizar a capacidade eosinofilogênica de cada helminto isoladamente, bem como a de suas associações;

12 - Atenção especial foi dada aos problemas da existência da hipereosinofilia nos casos com exames coprológicos negativos para helmintos, tendo-se passado em revista vários dos aspectos biológicos que o assunto comporta;

13 - Outra questão de grande importância clinica explanada neste trabatho é $a$ do encontro de casos de parasitismo por vermes, sem hipereosinofilia. o autor, baseado em seus dados e em outros colhidos na literatura sôbre

- Professor de Parasitologia Médica da Lniversialade Federal do Rio de Janeiro. 
o assunto, discute a fisiopatologia da eosinopoiese nas helmintoses e ojerece uma interpretaçâo para êste fato ainda não defintivamente esclarecido.

\section{O TEMA}

O trabalho que estamos apresentando resulta da observação dos exames hematológicos e parasitológicos das fezes de 2666 pessoas, operários e funcionários de duas emprêsas industriais, uma no Estado da Guanabara (The Sidney Ross Co.) e outra adjacente, no Estado do Rio (Petrobrás S.A.)

Tôdas as pessoas incluídas neste estudo são adultas, em sua maioria do sexo masculino e em condições de saúde a permitir o exercício de suas atividades nas respectivas Emprêsas.

Os exames realizados constituem parte da revisão médica periódica a que são submetidos aquêles operários e funcionários, em atendimento às disposições daqueles estabelecimentos industriais. Não são, pois, senão com algumas exceçōes, individuos consulentes dos Serviços Médicos que ali acorrem para dar queixa de seus males e receberem tratamento. Esta ressalva é importante para nós quando atingirmos $o$ momento de tirarmos as conclusões da nossa investigação. Nem por isso admitimos que as 2666 pessoas são higidas ou mesmo assintomáticas, uma vez que, como é notório, grande número de individuos, embora padecentes de doenças as mais diversas, comparecem ao trabalho cotidiano nessas e em tôdas emprêsas como as aqui observadas. E no caso, a revisão médica, colimando seu objetivo, descobre entre os trabalhadores doentes sintomáticos ou não, que sāo encaminhados ao tratamento. Nesse particular, grande número de nossos exames hematológicos e coprológicos deu sua contribuição, sobretudo quando o exame clínico por si só não permitia uma completa avaliação do grau de saúde do individuo examinado.

O tema de nossa investigação é a verificação da eosinofilia nos 2666 indivíduos nas condiçōes acima enumeradas, tanto naqueles com exames coprológicos negativos, quanto nos em que os exames revelaram o parasitismo por um ou mais helmintos isoladamente e em infestações duplas, triplas, quádruplas e quintuplas.
Outro objetivo é mostrar o sinergismo ou ação conjugada de dois ou mais helmintos na eosinopoiese.

Questão também a ser abordada é a da observação no grupo de indivíduos com exames coprológicos positivos para vermes, numerosos casos com eosinofilia normal ou mesmo a aneosinofilia e, ao contrário, no grupo com exames negativos, ao lado dos casos com eosinofilia normal e eosinopenia, casos com hipereosinofilia em graus variáveis.

Ao término do trabalho, e já com a análise dos dados aqui alcançados, ofereceremos sugestões para o encaminhamento do diagnóstico, prognóstico e tratamento das helmintoses intestinais.

E necessário dizer-se que os exames parasitológicos revelaram, além dos ovos e larvas de vermes intestinais, cistos de protozoários, em elevado percentual dos individuos, verificação esta que será apreciada em outra publicação.

\section{OS METODOS DE EXAME USADOS}

Os exames hematológicos foram feitos segundo a técnica e os cuidados habituais e constaram de hematimetria, dosagem de hemoglobina, determinação do volume globular e leucometria global e específica.

Os exames coprológicos foram feitos pelos métodos de Faust e ou Ritchie, de Willis, de Baermann e de sedimentaçāo, êste impròpriamente denominado de Hoffman, Pons e Janer, uma vez que a sedimentação havia sido proposta por Lutz em 1919 para pesquisa de ovos do Schistosoma mansoni. (34).

Em publicação anterior nós haviamos insistido na necessidade do emprêgo dos quatro métodos acima citados, para pesquisa dos parasitos intestinais e a continuidade de nosso trabalho veio confirmar nosso ponto de vista. (39).

Devemos entretanto considerar que 0 exame de fezes de um determinado dia poderá ser confirmado ou não em dia subseqüente. Goulart e cols. (25), em nosso Laboratório na Universidade Federal do Rio de Janeiro, estudando a variação da 
positividade dos exames de fezes para pesquisa de parasitos intestinais, verificaram, usando apenas o Método de Ritchie, grandes variações da positividade de um para cutro dia, fato êste que deve ser considerado judiciosamente em nosso estudo.

O fato de usarmos os quatro métodos de concentração não nos autoriza a considerar os resultados infalíveis, principalmente para a pesquisa das larvas do Strongyloides stercoralis, que muitas vêzes só vêm a ser observadas após vários exames em diferentes dias.

Mas, nessa investigação, em face do número relativamente grande de casos observados, o êrro diagnóstico isolado não modifica o resultado global, nem limita as inferências que dela podemos tirar.

\section{OS HELMINTOS ENCONTRADOS}

Parasitando as 2666 pessoas submetidas a inquérito foram encontrados, isoladamente ou em associações, os helmintos relacionados na Tabela $A$, onde se nota 0 número de vêzes em que cada um dêles foi observado e seus respectivos percentuais de freqüência. É de se lembrar que as infestações pelo Enterobius vermicularis e Taenia $s p$. não devem traduzir a realidade parasitária, pelo fato dos métodos de exame usados não serem os adequados à sua evidenciação.

Nosso trabalho não tem por objeto principal a verificação da frezüência dos helmintos nos grupos estudados, mas, de passagem, mostramos suas elevadas taxas de incidência, o que tem inestimável importância no conhecimento da epidemiologia das verminoses no meio de nosso operariado industrial.

E o que se poderia encontrar nos operários da agricultura em decorrência do seu baixo nível econômico e cultural?

\section{A EOSINOFILIA}

E a palavra que traduz a existência do eosinófilo no organismo, qualquer que seja sua localização: tecidual, liquórica, sanguinea ou humoral, esta em amplo sentido, incluindo outros líquidos normais e também os patológicos.

O estudo das variações da eosinofilia no homem e animais pressupõe a adoção de um critério de normalidade para a mes- ma a qual servirá como ponto de referência no estudo de suas variações fisiológicas e patológicas.

No estudo que empreendemos lidamos apenas com a eosinofilia sanguínea, embora saibamos que a dos tecidos e a de certos líquidos, como o liquor, possa apresentar variações importantes para a compreensão de certos processos mórbidos, tais como a meningite eosinofílica, os infiltrados de células eosinofílicas, os granulomas eosinofílicos e numerosas afecções de origem e patologia obscuras ou ainda nāo devidamente investigadas.

Aceitamos como válidas para a eosinofilia sanguinea normal a taxa de 1 a 4 eosinófilos por cento ( 1 a 4 Eo\%) e o número global de 200 a 300 por milímetro cúbico de sangue (200 a 300 Eo/mm3).

A verificação da taxa de eosinófilos $\dot{\epsilon}$ obtida pela contagem diferencial ou específica dos leucócitos em esfregaço de sangue corado segundo as técnicas da rotina hematológica e o número global, pela contagem direta em câmaras leucocitométricas empregando-se um líquido diluidor especial que, destruindo as hemátias e demais leucócitos, lhes realça suas caracteristicas.

E usual, entretanto, fazer-se a estimativa do número absoluto dos eosinófilos, estabelecendo-se a proporção entre 0 seu percentual obtido na contagem específica no esfregaço de sangue e o número global dos leucócitos obtídos na câmara de contagem.

No início dessa investigação tínhamos adotado essa conduta, também esposada por grande número de pesquisadores, mas preferimos substituí-la pela contagem diferencial, por julgar mais consentânea com as exigências científicas. Mas na verdade os estudos sôbre a eosinofilia sanguínea nas verminoses, feitos com base no número global dos eosinófilos obtido por aquêle artifício, são, sob muitos aspectos, comparáveis aos da eosinofilia relativa determinada pelo exame microscópico do sangue corado.

A desvantagem do cômputo indireto da eosinofilia absoluta decorre da dificuldade de se relacionar as variações da leucocitose com as helmintoses ou com outras doenças coexistentes ou intercorrentes. E assim consideraremos apenas a eosinofilia relativa $($ Eo\%). 
A ausência de eosinófilos nas lâminas de contagem, trađuzindo um número infimo dos mesmos no sangue periférico, denomina-se aneosinofilia. A esosinofilia normal inclui um número de eosinófilos variando de 1 a 4 Eo\%. A hipereosinofilia é tôda eosinofilia com 5 Eo\% e todos os valôres superiores a esta taxa. Poderemos eventualmente usar os têrmos eosinopenia e hipoeosinofilia que significam diminuiçāo das taxas de eosinófilos abaixo dos valôres normais. Há autores que empregam o têrmo eosinofilia para as hipereosinofilias e no consenso clínico geral as taxas de 1 a $2 \%$ Eo já são consideradas como eosinopenia.

$\mathrm{Na}$ prática, o que se considera como eosinofilia normal são as taxas de 1 - 2 3 e 4 Eo\% e compreendemos que êsse critério, sendo como é, convencional, dentro das variações biológicas, deve ser imperativamente adotado como ponto de partida para a avaliação das eosinofilias nas doen. ças parasitárias e nas não parasitárias.

Problema que defrontamos inicialmente é o da demarcação entre as eosinfilias fi.. siológicas e patológicas.

Há no organismo humano, da criança e dos velhos, dos adultos homem e mu. lher, fatôres fisiológicos normais, eosinopeniantes e eosinofilogênicos que dificultam a conceituação dos índices numéricos da eosinofilia normal.

Uma ampla dissertaçāo sôbre êsse problema foi escrita por Aschkenasy (2) analisando o papel dos hormônios na regulação da eosinofilia sanguínea e não menos importantes os dados experimentais de Halpern, Dominé e Fray, em 1962, (26) sôbre os mediadores químicos no mesmo fenômeno biológico, os de Fernex (22), e ainda a publicação de sintese de Deschiens e Benex, em 1962, (16) que tomamos por base nessa parte introdutória da análise dos dados de nossa investigação. Tantos artigos consultados, tantos pontos ainda obscuros no "caos" da eosinofilia, segundo o dizer de Lavier (33).

Numerosas publicações foram feitas sôbre êsse assunto e, dentre elas, no Brasil, as de Pessoa e Meira, em 1935, e Bacchi Naveira, em $1960(43,3)$, além de outras

Temos, entretanto, que evitar o emaranhamento das digressões na extensa literatura especializada nesse assunto.
A eosinofilia normal representa um estado de equilíbrio na produção, no armazenamento e liberação dos eosinófilos no organismo, assegurado por um jôgo de fatôres agindo sôbre o sistema fisiológico hipófiso-córtico-supra-renal vinculado aos setores do organismo encarregados da eosinopoiese.

Sem entrar em minúcias, consideremos as circunstâncias que promovem as oscilações fisiológicas na eosinofila normal.

IDADE - são mais amplas as modificações no número dos eosinófilos nos recém.nascidos e lactentes e nos velhos. Nestes, a tendência à eosinopenia parece decorrer mais da diminuição funcional do sistema endócrino, que da idade pròpriamente (5); naqueles, as variações tendentes para a hịpereosinofilia sāo mais nictemerais que contínuas, como mostram Gaubert e cols. (23).

RAÇA - para alguns autores, estudando o assunto na África e Ásia, os individuos da raça negra apresentam com maior freqüência oscilações na eosinofilia com aumento dos eosinofilos, atribuindo-se o fato a uma certa hipofunção da supra-renal, em comparação com a raça branca (16).

VARIAÇÕES NICTEMERAIS - São variáveis mais às atividades do indivíduo que pròpriamente a fatôres ciclicos diários. Mas há de fato variações do teor dos eosinófilos no sangue circulante verificadas por vários autores e consignadas em textos de hematologia (52). A principal variação é uma eosinopenia matutina dependente de estímulos externos, Iuz e ruídos, segundo as interessantes observaçóes de que os cegos e os surdos não a apresentam, fatos êstes citados por Deschiens e Benex (16) .

Há mesmo referências a ritmos eosinofílicos, referidos por Deschiens e Benex, de três tipos de variações nos individuos normais. (36).

FATORES ESTACIONAIS E ALIMENTARES - A partir de observações e experiências de vários autores em animais de la- 
boratório, podemos admitir a existência de variaçōes de eosinofilia sanguínea do homem, decorrentes das condições climáticas e dos regimes alimentares. Estas condições provàvelmente influenciam as reações hi pofisárias, diminuindo a eosinopoiese no homem e acentuando-a na mulher, graças ao incremento dos hormônios sexuais dependentes daqueles fatôres.

FATÔRES LIGADOS AO SEXO - Graças aos trabalhos experimentais de diferentes investigadores, sabe-se que os estrógenos incrementam a taxa de eosinófilos enquanto os andrógenos a diminuem; daí a tendência ao aparecimento da hipereosinofilia na mulher e da eosinopenia no homem. Há também, no curso da gravidez, variaçōes temporárias na eosinofilia, havendo eosinopenia nos seis primeiros meses, elevação no $7 .^{\circ}$ e $8^{\circ}$ meses e nova queda no último (Vouilloux, 1955), citado por Deschiens et Benex (16). Ainda no tópico concernente às variações da eosinofilia, de um para outro momento outros fatôres poderiam ser lembrados, tais como a atividade eosinofilizante da tireóide, do fígado, do estômago. De outro lado, são eosipeniantes os estímulos físicos e psíquicos, tais como o calor, o frio, os estorços musculares, as emoções, as tensões nervosas. E, em dado momento, torna-se difícil discernir o limite entre as eosinofilias fisiológicas e as patológicas, tanto no sentido da eosinopenia, quanto no das hipereosinofilias. Além das causas fisiológicas determinantes das variaçōes da eosinofilia sanguínea, devemos considerar como fatôres determinantes dessas variações certos recursos terapêuticos, tanto físicos quantos químicos. A exposiçāo às substâncias radioativas $\mathrm{e}$ aos raios $\mathrm{X}$ é eosinofilizante, como também numerosas substâncias químicas medicamentosas como o ferro e seus sais, os sais de ouro, a cobalamina, a isoniazida, a estreptomicina, a foliculina, o extrato de fígado. De ação eosinopeniante são os corticosteróides, a adrenalina, o hormônio sexual masculino, os anti-histaminicos de sintese, o salicilató de sódio.

Tantos são os fatôres naturais cotidianos capazes de modificar a normalidade da eosinofilia sanguínea, que seríamos inclinados a considerar irrelevantes suas variações nas verminoses, não fôsse o caráter particular que ela apresenta nessas afecçōes. Por isso cresce o interêsse do hemograma como método auxiliar de diagnóstico e avulta a necessidade de sua atenta interpretação, principalmente na diferenciação das eosinofilias parasitárias $e$ não parasitárias.

\section{HIPEREOSINOFILIAS PARASITÁRIAS E NÃO PARASITÁRIAS}

O estudo desta questão, das mais importantes para uma judiciosa interpretaçāo do hemograma nas helmintoses, tem sido tentado por vários autores, a alguns dos quais nos reportamos para preparar a parte inicial desta publicação. Citamos apenas aquêles de que nos valemos, deixando sem citação os que são prescindiveis para o objeto dêste trabalho.

Valho-me inicialmente dos trabalhos fundamentais de Lavier (32, 33) e da erudita publicação de Deschiens, em 1962, (15), de onde colhemos os dados para a apreciação dos resultados obtidos em nossa pesquisa. Aqui outra vez me escuso de enveredar pela extensa bibliografia sôbre as eosinofilias.

As hipereosinoflias podem ser classificadas inicialmente em três grupos: - 1.0 - Hipereosinofilias dependentes de processos mórbidos diversos, mais ou menos bem definidos; $2^{\circ}$ - Hipereosinofilias idiopáticas, raras, mal definidas, onde se poderia incluir a discutida eosinofilia familial; 3.' Hipereosinofilias leucêmicas raras.

O primeiro grupo se divide por sua vez em dois subgrupos: $10^{\circ}$ - Hipereosinofilias não parasitárias; $2 .^{\circ}-$ Hipereosinofilias parasitárias.

As hipereosinofilias' não parasitárias mais importantes podem ser observadas com freqüência variável nos seguintes processos mórbidos: a) - Em certas dermatoses como o pênfigo, as eritrodermias de origem medicamentosa, o eczema, o eritema eosinofílico (30) e outras; b) - Na convalescença de infecçōes, como indica. doras do restabelecimento das defesas orgânicas; c) — No curso da escarlatina, constituindo uma exceção entre as doencas infecciosas, nas quais se observa habitualmente, eosinopenia; d) - Nos estados alérgicos, como a asma e a rinite; 
e) - Em certas colagenoses como o reumatismo e a periarterite nodosa; f) - Em várias doenças de patologia não conhecida em definitivo, como os granulomas de eosinófilos da pele e músculos, a multiviscerite de eosinófilos de Turiaf, a doença de Hodgkin e outras. É de se lembrar também as hipereosinofilias que certos individuos apresentam decorrentes do uso prolongado de alguns medicamentos ou de irradiações, como nos referimos anteriormente, e ainda de intoxicações profissionais pelo benzol.

Não somos tão otimistas quanto Deschiens (15) e Bonnin e Moretti (7) em relação à possibilidade de diferençar as hipereosinofilias não parasitárias das parasitárias, porque no mecanismo fisiológico regulador da eosinofilia sanguínea em ambos os grupos há um conjunto de variáveis pertinentes ao organismo e outro aos fatôres eosinofilisantes ou eosinope-niantes.

Para se dominar todo o problema da regulação da eosinofilia, haveríamos de conhecer bem a origem, o comportamento e o destino dos eosinófilos, haveríamos de encontrar as leis que governam o equilíbrio da eosinofilia tecidual e sanguínea no binômio mastócito-sosinófilo, e haveríamos de precisar o papel do sistema neuro-hipófise-supra-renal na eosinopo-ese, através da atividade dos mediadores químicos. Essa exigência intelectual se impõe em face das dificuldades que encontramos na prática para ajuizarmos até que ponto uma eosinofilia seria dependente de uma infestação helmíntica ou de um fator não parasitário ou ainda de sua associação.

E nesta questão temos que raciocinar dialèticamente, procurando reconciliar as aparentes contradições surgidas ocasionalmente pelo fato de se observar no grupo de indivíduos não parasitados alguns com grandes hipereosinofilias e, ao contrário, nos parasitados, outros com aneosinofilia.

Um dado experimental subsistente entre os variáveis podemos reter: Deschiens e Poirier (17) induziram em cobaias, pela inoculação de extratos de Fasciola hepática, hipereosinofilias de taxa elevada, ir redutiveis pelo A.C.T.H. (Test de Thorn negativo). Nesta experiência se estabeleceram nas cápsulas supra-renais dêsses animais profundas alteraçōes necróticas e hemorrágicas. Em outras cobaias tratadas pelo extrato de pimenta da Guiné, ou do tabaco, ou pela estreptomicina surgiu uma hipereosinofilia moderada redutível pelo A.C.T.H. (Test de Thorn positivo) e, correlatamente, nas cápsulas supra-renais apareceram lesões muito menos acentuadas, não passando da congestão e hiperplasia. Nestas duas experiências e nas de Fernex (22), se encontram parte dos fun-. damentos que permitem uma tentativa de explicação da fisiopatologia das hipereosinofilias e hipermastocitoses e uma esperança para estabelecer uma distinção válida entre as hipereosinofilias parasitárias e não parasitárias. Ainda que nos coloquemos nessa atitude de reserva em face do valor de uma eosinofilia anormal, podemos, em cada caso isolado, reunindo todos os recursos semiológicos a êsse dado hematológico, chegarmos a uma útil interpretação diagnóstica.

Do ponto de vista prático podemos resumir as principais diferenças ent"e as hiperreosinofilias parasitárias e não parasitárias nos seguintes tópicos:

\section{HIPEREOSINOFILIAS PARASITÁRIAS}

- a) - As hipereosinofilias médias (10 a 18 Eo\%) e altas $(>19$ Eo\%) são mais freqüentes; b) - No parasitismo pelos helmintos as modificações das taxas das hipereosinofilias no correr do tempo se traduzem por uma curva de forma constante, na qual se observam três períodos: $1^{\circ}-$ latência - correspondendo à invasão e alojamento do parasito no organismo; $2 .^{\circ}$ - ascensão - inicialmente rápida, logo a seguir lenta e mantendo-se em "plateau" tempo variável; $3 .^{\circ}$ - queda - rápida no início, tendendo lentamente a se tornar paralela ao eixo do tempo e, segundo a observação de nossos casos, descendo abaixo da abcissa; c) - Teste de Thorn negativo nas eosinofilias altas, podendo ser positivo nas eosinofilias médias e baixas. (Fig. 1).

HIPEREOSINOFILIAS NÃO PARASITARIAS - a) - As hipereosinófilias não parasitárias são, via de regra, baixas (5 a 9 EO\%); b) - A curva eosinofílica é irregular, com inflexões sucessivas, tomando por vêzes o aspecto de "dentes de serra", salvo nas hipereosinofilias cujo fator é um tóxico químico ou uma irradiação de 
atuação contínua. (Fig. 2); c) - O teste de Thorn é, na maioria dos casos, positivo, traduzindo pouco comprometimento das cápsulas supra-renais.

E necessário não perder de vista que a curva eosinofílica de Lavier em cada indivíduo traduz um fenômeno evolutivo cujas etapas cronológicas variam nas diferentes helmintoses e pode sofrer alterações dependentes de causas intercorrentes eosinopeniantes, como certas doenças infecciosas, ou eosinofilogênicas, como alguns medicamentos (estreptomicina, salicilato de sódio e outros).

$\mathrm{Na}$ altura desta exposição se apresentam duas perguntas que traduzem, como acentuamos anteriormente, uma contradição a nos exigir um raciocínio dialético.

PRIMEIRA PERGUNTA: Por que num grupo de indivíduos com exames de fezes negativos para helmintos há alguns com hipereosinofilia?

SEGUNDA PERGUNTA: Por que num grupo de indivíduos com exames coprológicos positivos para helmintos alguns não apresentam hipereosinofilia sanguínea?

As respostas a estas perguntas serão oferecidas após a apreciação dos dados contidos neste trabalho, como parte das conclusóes a que chegamos.

\section{DISTRIBUIÇÃO DOS CASOS PELAS EOSINOFILIAS}

Dos 2.666 indivíduos examinados, 1941 apresentaram exames coprológicos positivos para um, dois, três, quatro ou cinco helmintos.

A distribuição do número de casos positivos e seu respectivo percentual pelos graus crescentes de eosinofilia se alinha na Tabela $B$ ao lado da distribuição dos casos com exames coprológicos negativos para helmintos.

A análise dos dados desta Tabela mostra sumàriamente os crescentes percentuais de casos positivos com hipereosinofilias médias e altas, em contraposição com os negativos nos quais êsses percentuais tendem a baixar (Gráfico 1 - Tabela I) .

Poucas são as referências bibliográficas referentes a essa questão, das quais refiro-me à de Morvan, Voizard e Baise (40), na qual são estudadọ 701 casos, sendo 372 parasitados por vermes e 329 negativos.
Os resultados da investigação dêstes autores, no tocante ao número de casos nos dois grupos de indivíduos com e sem eosinofilia respectivamente, são confirmados em nossa pesquisa.

$O$ estudo da distribuição dos casos positivos e negativos, comparativamente pelas eosinofilias, servirá de referência nas observações subseqüentes relativas aos vermes estudados.

Em virtude de serem escassos na literatura médica os dados numéricos sôbre a eosinofilia no parasitismo isolado por um verme e nas diferentes modalidades de associação parasitária, apresentamos as tabelas seguintes que evidenciam, em combinação com os gráficos, êsse aspecto da eosinofilogênese nas infestações verminóticas. (Tabelas C, D, E, F.)

Os gráficos 2, 3, 4, 5 colocam em evidência a distribuição dos casos pelos graus de eosinofilia nas infestações isoladas pelo Trichuris trichiura, Ascaris lumbricoides, Necator americanus e Strongyloides stercoralis. Quanto aos demais helmintos, em virtude do pequeno número de observações, não são apresentados seus valôres estatísticos.

(Para facilidade de redação consideramos a notação Necator americanus incluindo Ancylostoma duodenale, por não ser possível a distinção dos ovos dêstes nematódeos)

Trichuris trichiura - Gráfico 2 - Tabela II.

Ascaris lumbricoides - Gráfico 3 - Tabela III.

Necator americanus - Gráfico 4-Tabela IV.

Strongyloides stercoralis - Gráfico 5 Tabela V.

O gráfico número 13 mostra em colunas os percentuais de eosinofilia nos casos de parasitismo pelos quatro nematódeos e, comparativamente, nos negativos.

Os citados gráficos ilustram com segurança as diferenças da capacidade eosinofilogênica dos quatro parasitos em aprêço, os quais se escalonam na seguinte ordem crescente: Trichuris, Ascaris, Necator e Strongyloides.

Para dar norma à avaliação da capacidade eosinopoiética, estabelecemos o indice eosinofílico que traduz, tanto no grupo de indivíduos com exames positivos para helmintos quando no de exames negativos, 
respectivamente, a relação entre o número de pessoas com hipereosinofilia $e$ as que não a apresentam.

Este índice (I.Eo) é, portanto, o quociente da divisão do número de pessoas com hipereosinofilia (EO $>5 \%$ ) pelo das pessoas com eosinófilos abaixo de $5 \%$ (Eo $<5 \%$ ), em determinado grúpo com exames positivos ou negativos.

Reportando-nos à Tabela $B$, podemos estabelecer os I. Eo (índice éosinofílico) para os casos positivos e negativos, respectivamente:

Grupo dos Positivos:

$$
\begin{aligned}
& \text { Com Eo }>5 \%=60,22 \% \\
& \text { Com Eo }<5 \%=39,67 \%
\end{aligned}
$$

$$
\text { I. Eo }=\frac{60,22}{39,67}=1,51
$$

Grupo dos Negativos:

$$
\begin{aligned}
& \text { Com Eo }>5 \%=37,10 \% \\
& \text { Com Eo }<5 \%=62,89 \% \\
& \text { I. Eo }=\frac{37.10}{62,89}=0.58
\end{aligned}
$$

Ao índice eosinofílico do total dos casos positivos para vermes denominamos $I$. EO médio e ao dos casos negativos I. Eo residual. Esta conceituação de índices médio e residual será aproveitada neste trabalho para discussão do problema das hipereosinofilias nos casos com exames de fezes negativos para helmintos.

Com o estabelecimento do I. Eo podemos ajuizar a capacidade eosinofilogênica de cada um dos vermes nos grupos de casos de parasitismo isolado ou em associações.

As tabelas G, H, I e J, informam-nos os índices eosinofílicos observados nas infestações por um, dois, três e quatro vermes, fato êste de importância prática indiscutivel.

Pela inspeção já se pode perceber o possível efeito conjugado ou sinérgico de um ou mais vermes na eosinopoiese e descobrir quais as associações mais potentes a desempenhar essa função, sendo fácil verificar que o Strongyloides é o potencializador mais eficaz naquelas associações.

Comparando-se as curvas de distribuição dos casos pelos graus de eosinofilias do Trichuris (Gráfico 2 - Tabela II), do Ascaris (Gráfico 3 - Tabela III), do $\mathrm{Ne}$ cator (Gráfico 4 - Tabela IV) e do Strongytoides (Gráfico 5 - Tabela V), observa-se o crescente afastamento de suas respectivas curvas da curva dos casos negativos, na ordem da sua atividade eosinofilogênica. Nota-se desvio da curva para cima e para a esquerda em Trichuris e $A s-$ caris no sentido das hipereosinofilias baixas, bem como das eosinofilias normais e da aneosinofilia e, ao contrário, desvio para direita e para cima no sentido das hipereosinofilias médias e altas em Necator e Strongyloides (Gráfico 6 - Tabela VI) .

\section{EOSINGFILIAS NAS ASSOCIAÇÕES PARASITÁRIAS}

O estabelecimento dos índices eosinofílicos I. Eo já mostrados anteriormente permitiu-nos velrificar que nas associações - de dois ou mais parasitos há, na maioria delas, aumento das hipereosinofilias em comparação com as observadas em cada um dêles, isoladamente.

De fato, há interações entre os associados, mas não temos elementos para determinar se há ação eosinofilogênica sinérgica ou conjugada ou se um dos vermes potencializa a ação de um dêles.

Para obtermos uma visão de conjunto da atividade eosinofilogênica das associações, erigimos os gráficos das associações Ascaris-Trichuris (Gráfico 7 - Tabela VII), Necator-Trichuris (Gráfico 8 - Tabela VIII), Ascaris-Necator (Gráfico $9-$ Tabela IX), Trichuris-Strongyloides (Gráfico 10 - Tabela X), Ascaris-Strongyloides (Gráfico 11 - Tabela XI) e NecatorStrongyloides (Gráfico 12 - Tabela XII) .

O exame dos gráficos e das tabelas que thes correspondem, mais do que uma prolixa explicação, põe em relêvo as influências recíprocas dos helmintos associados. $\mathrm{Na}$ associação Ascaris-Trichuris há discreta diminuição dos casos com aneosinofilia e eosinofilia normal e aumento das hipereosinofilias baixas e altas (I.Eo = $=1,14)$; na Necator-Trichuris não há ação potencializadora do Trichuris sôbre o $\mathrm{Ne}$ cator no sentido de aumentar o número de casos com hipereosinofilia, porém notá-se aumento das hipereosinofilias altas (I. Eo $=1,70)$; na Ascaris-Necator há acentuado aumento das hipereosinofilias 
com predominância das hipereosinofilias médias (I. Eo $=2,12$ ) ; na Trichuris-Strongyloides, de I. Eo $=3,00$, não há aumento das hipereosinofilias em relação ao strongyloides ( $\mathrm{I}$. Eo $=3,37$ ), porém há aumento das eosinofilias normais e hipereosinofilias baixas, sugerindo ação inhibidora do Trichuris (I. Eo $=0,67$ ), sôbre o Strongyloides; na Ascaris- Strongyloides, de I. Eo $=4,33$, desaparecem as aneosinofilias e caem as eosinofilias normais, havendo acentuado aumento das hipereosinofilias baixas, traduzindo um processo biológico aparentemente paradoxal; e finalmente na associação Necator-Strongyloides (I. Eo $=6,46$ ) também desaparecem as aneosinofilias e baixam ainda mais as eo-sinofilias normais aumentando as hipereosinofilias médias de modo muito acentuado.

Nas associações triplas e quádruplas os indices eosinofílicos são sempre elevados com as curvas de cada um dos helmintos associados, tendendo para o paralelismo. Êstes resuitados, não há como negar, eram esperados, mas desconhecidos em suas minúcias. Desconhecida era a capacidade eosinofilogênica de cada um dos nematódeos estudados sob êste ponto de vista e também as interações entre êles, agora esboçada nesta investigação.

Das poucas publicaçōes sôbre a eosinofilia nas infestações mistas por helmintos, cabe referência a de Costa \& cols, em 1960 (12) na qual são estudadas três associações, cujos dados transcrevo para ccmparação com os nossos:

1. - Ascaris - Ancilostomídeo-tricocéfalo - 53 pessoas.

Com hipereosinofilia: 39 casos.

Sem hipereosinofilia: 14 casos.

Nesta associação o indice eosinofílico extraído por nós é I. Eo $=$ $=39=2,78$, próximo ao encon$\overline{14}$

trado em nosso trabalho nesse tipo de associação.

\footnotetext{
2.0 - Ascaris - Ancilostomídeo - 24 pessoas.

Com hipereosinofilia: 14 casos.

Sem hipereosonifilia: 10 casos.

I. Eo $=14=1,4$, menor rue 0 en$\overline{10}$
}

contrado entre as observações do nosso trabalho, que foi 2,12 .

3. - Ascaris - Ancilostomideo-Strongyloides-tricocéfalo - 19 .

Com hipereosinofilia: 16 casos.

Sem hipereosinofilia: 3 casos

I. Eo $=\frac{16}{3}=5,33$, mais baixo,

porém próximo do encontrado nesta publicação que foi 6,24 .

E habitual, em trabalho da natureza dêste, enfatizar o poder eosinofilogênico dos vermes pela taxa de eosinófilos no sangue dos indivíduos por êles parasitados, tanto mais alta esta, quanto mais forte aquêle poder.

Os dados numéricos dêste trabalho não confirmam essa suposição, pelo menos nas pessoas aqui estudadas. As eosinofilias altas podem ser observadas em tôdas as infestaçōes simples ou mistas, na dependência não só do verme em causa, como do tempo do parasitismo e de outros fatôres ligados ao organismo. O poder eosinofilogênico é medido pelo indice eosinofílico (I. Eo) agora proposto por nós, o qual é aplicado não ao caso isolado, mas aos grupos humanos sujeitos ao estudo. Essa conceituação do poder eosinofilogênico não invalida o significado clínico de uma elevada hipereosinofilia como dado semiológico importante no diagnóstico de uma helmintose. Essa alteração hematológica não é exclusiva de um único verme c em cada um dêles poderá variar cronològicamente, uma vez que, como já anotamos, a eosinofilia sanguinea é um processo biológico evolutivo, em andamento. E por isso que se encontram nas infestacóes pelo Trichuris, pelo Ascaris, pelo $\mathrm{Ne}$ cator e pelo Strongyloides, cada um dêles com seu indice eosinofílico próprio, eosinofilias dos mais diversos graus. $O$ mesmo se poderá afirmar para as infestações mistas.

CASOS COM EXAMES COPROLÓGICOS NEGATIVOS PARA HELMINTOS COM HIPEREOSINOFILIA

E do conhecimento de todos os autores que trabalham neste assunto a existência de casos com exames de fezes negativos e 
elevada taxa de eosinófilos no sangue. Nossa pesquisa mais uma vez evidencia êsse fato, verificando-se, em 725 pessoas com exames de fezes negativos das $\mathbf{2 . 6 6 6}$ examinadas, $269 \mathrm{com}$ a taxa de eosinófilos acima de $5 \%$. Os 269 indivíduos com exames de fezes negativos com hipereosinofilia correspondem a $37,10 \%$ do total dos casos negativos. (Tabela $B$ ).

Em face dêste resultado, fazêmo-nos a seguinte indagação: Por que um tão elevado número de pessoas com exame de fezes negativo para vermes, apresenta hipereosinofilia sanguínea?

Faremos uma tentativa para explicar essa descorrelação, não esperada em grande número de casos clínicos e que poderia desvalorizar o subsídio que o hemograma nos oferece para o diagnóstico das helmintoses.

Em tópico anterior estabelecemos o conceito de eosinofilia residual determinada pelo índice eosinofílico (I.Eo) dos casos negativos, o qual é a relação entre o número de casos com Eo $>5 \%$ e o Eo $<5 \%$. Nessa conceituação a eosinofilia residual traduz num grupo de individuos o número de casos mostrando hipereosinofilia sem causa aparente imediata.

$\mathrm{Na}$ presente pesquisa, em 725 individuos negativos, o indice eosinofílico (I. Eo) é: 269 dividido por 453 ou 0,58 . Esse índice, como em qualquer outra pesquisa com êsse objetivo, tenderá a diminuir à medida que se puder demonstrar a causa eosinofilogênica em cada caso isolado, seja ela verminótica ou não.

Demonstraremos, com fundamento numa investigação subsidiária e paralela a esta, que $\mathrm{I}$. Eo $=0,58$ dos nossos casos negativos poderá ser alterado para valôres mais baixos, à proporção que se fôr descobrindo, com a repetição dos exames de fezes, dentre os casos inicialmente negativos, a presença de helmintos (Tabelas $\mathrm{K}$ e $\mathrm{L}$ ).

Excluídas clinicamente tôdas as causas eosinofilizantes não parasitárias que possam atuar nos indivíduos de um determinado grupo, somos inclinados a considerar que a eosinofilia residual nêle observada é dependente de uma infestação verminótica não diagnosticada nos exames iniciais. Mas na prática médica muitas vêzes não chegamos a diagnosticar uma helmintose, mesmo com provas imunológicas, e, neste caso, estariamos em face de uma hipereo- sinofilia "idiopática" que muitos autores teimam em rotular como sindromes de Loeffler ou de Weingarten ou ainda eosinofilia tropical.

Os resultados da referida investigaçāo consignados nas tabelas $K$ e $L$ demonstram que em 40 pessoas com hipereosinofilia e negativos para Strongyloides stercoralis no exame coprológico inicial, 20 foram positivas para êsse parasito na primeira repetição ou nas subseqüentes, enquanto as outras 20 ainda continuaram negativas. Houve nessa pesquisa, redução de $\mathbf{5 0 \%}$ dos casos negativos com hipereosinofilia. Seria uma tentação tirar dêste resultado uma inferência para os nossos 269 casos, exibindo idêntica situação que passariam para 134 ou 135 o que modificaria profundamente os dados estatísticos dessa trabalhosa pesquisa. $\mathbf{E}$ se pensarmos em têrmos da teoria matemática dos limites, êsses números caíriam inexoràvelmente para zero sem chegar a êle.

Para dar resposta à pergunta inicial enumeraremos as causas que falseiam os resultados dos exames coprológicos:

-
a) Causas técnicas;
b) causas medicamentosas;
c) causas biológicas.

CAUSAS TECNICAS - As principais causas técnicas que falseiam os resultados dos exames de fezes são a tomada do material para exame em quantidade exígua, a sua consistência e o tempo decorrido entre sua emissão e o exame. Usando-se, como recomendamos, quatro ou cinco métodos diferentes, é necessário um mínimo de 20 gramas de fezes para o conjunto dos mesmos. Qualquer explicação sôbre êsse fato é óbvia. As fezes moldadas, de consistência compacta, não libertam as larvas do Strongyloides stercoralis em número suficiente para serem observadas ao exame microscópico, empregando-se o método de Baermann que é o indicado para sua pesquisa. Nessa eventualidade recomendamos um laxativo salino que poderá positivar uma pesquisa inicial negativa.

O alongamento do tempo entre a emissão e o exame das fezes poderá criar dificuldade, felizmente removível, para a identificação das larvas do strongyloides 
e Ancilostomídeos. Ocorrência rara é o encontro de larvas de nematódeos de vida livre na água de extração do aparelho de Baermann ou nos cálices de sedimentação, larvas-pré-existentes na água de reservatórios que abastecem os laboratórios, como já observamos.

CAUSAS MEDICAMENTOSAS - O emprêgo de medicamentos, nem sempre determinados, poderá constituir uma causa de êrro, interrompendo temporàriamente a postura dos ovos e larvas aos vermes intestinais ou prejudicar a motilidade destas de tal modo e tornar ineficaz o método de Baermann para sua pesquisas, uma vez que nêle são aproveitados o hidro e o termotropismio das mesmas.

CAUSAS BIOLÓGICAS - É conhecida a existência de periodo de interrupção temporária na eliminação de ovos e larvas de vermes intestinais sem causa aparente. Chaia (10) havia verificado o fato nas in:festações pelo strongyloides $e$ Vianna Martins (49) pelo Schistosoma. Goulart e cols. (25), em estudos realizados em nosso laboratćrio, pôde assinalar, em meticulosa pesquisa, períodos de positividade intercalados irregularmente com os de negatividade. Usando apenas o Telemann, modificado por Ritchie como método de exame coprológico, demonstraram êsses autores em 44 indivíduos observados durante 33 dias, grandes variações entre os casos, no tocante à regularidade de eliminação de cistos de protozoários e de ovos $\epsilon$ larvas de helmintos, em dias diferentes.

Do trabalho de Goulart e cols. extraímos os seguintes dados que comprovam a existência de casos de parasitismo, nos quais os exames coprológicos são, em diferentes dias, sucessivamente positivos ou irregularmente positivos ou negativos:

Para o Trichuris, as diferenças de positividade variaram, num grupo de 39 pessoas examinadas, desde um único exame positivo em 19 amostras de fezes de dias diferentes, até o máximo de 12 positivos no total de 12 amostras, e, entre êstes extremos, tôda sorte de variações; observou-se um caso cujas fezes foram examinadas cm 19 dias, sendo os exames positivos apenas duas vêzes, e, de 20 amostras de outro caso do mesmo grupo, tôdas as amostras foram positivas; para o Necator, em um grupo de 5 casos positivos, observou-se um com 15 amostras de fezes de dias diferentes, das quais uma só foi positiva e, em outro com 11 amostras, tôdas foram positivas; finalmente para o Strongyloides, em 9 casos positivos, observou-se um caso com 9 amostras, das quais uma apenas foi positiva e de outro caso, com 12 amostras estudadas, nove revelaram as larvas do parasito.

O estudo de Goulart e cols., quase por si explica a possibilidade da existência de indivíduos com hipereosinofilia tendo exames coprológicos negativos para vermes.

Outro aspecto do problema da hipereosinofilia em pessoas com exame de fezes negativos é o relacionado com outros helmintos, dos quais nāo se encontram, habitulamente, ovos nos exames coprológicos como o Enterobius vermicularis, a Taenia solium e a $T$. Saginata, e, além dêstes, outros vermes cujos ovos, em determinadas fases da doença, não são eliminados, como o Schistosoma mansoni.

O Enterobius e as duas espécies de Taenia, embora de fraco poder eosinofilogênico, poderiam, pelo motivo citado, contribuir para elevar o número de casos negativos com hipereosinofilia, criando uma idéia irreal em tôrno da questão.

A propósito do assunto, referimos às observaçōes de Deane (14) e de Goulart (24), demonstrando a elevada freqüência do $E n$ ierobius em grupos humanos, onde os recursos de rotina de laboratório não haviam revelado senão pequeno número de casos positivos.

E, relativamente ao Schistosoma manso$n i$, de elevado poder eosinofilogênico, é bem conhecida a eventualidade dos exames de fezes não revelarem, senão em sucessivas repetições, a presença de ovos do parasito, sendo por isso requeridos outros recursos como a biópsia retal, a intradermorreaçāo e outras provas imunológicas para o diagnóstico da esquistossomose.

Temos nestes aspectos doutrinários mais uma explicação para as hipereosinofilias sem causa aparente ou errôneamente relacionadas a outras entidades mórbidas nāo parasitárias.

Outra circunstância a ser considerada na solução da questão de que agora nos ocuparnos é a verificação de infestações apenas por machos, como se observa com alguma freqüência entre nós. Nesse tópi- 
co, refiro-me, de segunda mão, às investigações de Yokogawa e Wakeshima (53) que assinalam, em um grupo de pessoas de Formosa, 3,34\% parasitados exclusivamente por machos do Ascaris lumbricoides.

Outra referência ao assunto se deve a Hsu e Chow (28) que em 809 autópsias realizadas durante anos encontraram 312 com Ascaris no intestino; entretanto, em 149 pessoas dêste grupo, nas quais se pesquisou os ovos dêsse verme nas fezes em vida, em apenas 105 o resultado foi positivo $(70,4 \%)$; e no mesmo trabalho de Hsu e Chow é enunciado que daqueles 312 casos com Ascaris encontrados nas necrópsias, 30 tinham sòmente formas masculinas $(9,6 \%)$. Em virtude da conhecida atividade eosinofilogênica do Ascaris, é lógico se admitir que casos com hipereosinofilia sem ovos nas fezes poderiam estar infestados sòmente pelos machos dêsse verme.

E comum se observar nas fezes de algumas pessoas apenas ovos não fecundados dêsse parasito, indicando o parasitismo exclusivo por fêmeas e seria lícito pensar na possibilidade de casos que fôssem parasitados sòmente pelos machos, uma vez que ambos os sexos estão sujeitos às mesmas contingências do acaso, em relação ao determinismo sexual das formas infestantes.

Dos fatos observados e da argumentação relativos ao Ascaris, poderíamos tirar ilaçōes para o Trichuris, o Necator, o Enterobius e o Schistosoma.

A presença de hipereosinofilia em pessoas em que a ovo-helmintoscopia é negativa, ainda poderá ser explicada pela imaturidade das fêmeas nos períodos iniciais do parasitismo ou nos tardíos, em que a vitalidade das mesmas esteja diminuída ou mesmo abolida.

to conhecimento médico geral o fato de que no período de invasāo do organismo pelos vermes há, em grande número de casos, um conjunto de manifestações reacionais, dentre as quais uma é a hipereosinofilia sanguínea. Esta alteração hematológica é encontrada nos dias imediatos que se seguem à introdução no organismo das formas infestantes, do Schistosoma mansoni $(37,42)$ e dos nematódeos que apresentam uma fase pulmonar transitória antes de se estabelecerem e completarem sua maturidade nos pontos de sua localização definitiva. $(4,9,29,31)$.
Como subsídio à apreciação dêsse assun to, são bastante sugestivas as observaçõe de Faust em 1933, (21) em primatas infes tados experimentalmente por strongyloi des, nos quais foram encontradas, no re cesso da parede intestinal, "post-funciona females" e "degenerate females", suscitan do reações do organismo, dentre as quai poderia estar presente a hipereosinofili sanguínea.

Circunstância análoga é a descrita po vários autores na esquistossomose, na qual segundo Meira (37) pode ocorrer um "pneumonia por verme morto", ou forma clínicas com sintomatologia manifesta, en casos com exames de fezes negativos par: ovos de parasito, porém com reações imu nológicas positivas para a doença.

Um aspecto do problema das hipereosi nofilias ainda não devidamente apreciad no Brasil é o da possibilidade da existên. cia de casos de infestações do homem pol larvas de parasitos de animais doméstico e silvestres, estabelecendo-se uma situaçãc biológica de "impasse parasitário", segundo a expressão de Harant, em 1962 (27) . Exemplos dêsse "impasse parasitário" sãc a "larva migrans" tegumentar ocasionada por larvas infestantes de ancilostomídeos de carnivoros domésticos e a "larva migrans" visceral, pelas de ascarídeos dêstes mesmos animais. Em várias áreas do Extremo-Oriente, incluindo-se também a Polinésia, têm sido descritos casos de "meningite à eosinophiles" ocasionados por larvas do Angiostrongylus cantonensis, parasito do rato no estádio adulto e de moluscos e crustáceos dulcícolas no larvário. Essa afecção inclui casos com sintomatologia variável, tanto benignos quanto graves e mesmo fatais e nêles há coexistência na hipereosinofilia liquórica e sanguínea.

Em casos de "síndrome de Loeffler", de "eosinofilia tropical" ou "síndrome de Weingarten" poderíamos reconhecer, com Schneider (47) e Blanc et Nosny (6), além dos vermes que têm no homem seu hospedeiro normal, vermes de outros animais como certos filarídeos (Brugia malayi de macacos asiáticos, Dirofilaria immitis do cão doméstico cosmopolita e Brugia pahan$g i$ do gato doméstico, dentre outros), desempenhando o papel de agentes eosinofilogênicos.

Fatos como os aqui assinalados devem ser considerados como fatôres, ainda que 
difíceis de ser demonstrados, como capazes de explicar as taxas elevadas de eosinófilo no sangue de pessoas com exames parasitológicos negativos para vermes e nas quais nenhuma outra causa alérgica ou tóxica aparente pudesse ser revelada.

Terminando essa parte de nossa exposiçāo, desejamos fazer referência à hipereosinofilia em outras doenças parasitárias, porém não verminóticas. Dêsse tipo foram descritos por Van der Sar, em 1962, (48) casos de hipereosinofilias sanguíneas em indivíduos com as vias respiratórias infestadas por ácaros inferiores dos gêneros Tyroglyphus e Tarsonemus, em Curaçao. Êsse autor faz referências a experiências sôbre infestação da traquéia de macacos nos quais surgiu uma hipereosinofilia de 24\% EO.

Não deve ser subestimada a existência da hipereosinofilia em casos de escabiose, consignados pelos tratadistas como Neveu-Lemaire (41) e Callot e Helluy (8), tanto na forma simples, não complicada, quanto na crostosa.

CASOS COM EXAMES COPRCLÓGICOS POSITIVOS PARA HELMINTOS SEM HIPEREOSINOFILIA

Na prática médica, são freqüentes os casos de indivíduos parasitados por vermes intestinais que apresentam uma eosinofilia normal ou mesmo uma aneosinofilia.

Alguns autores que trabalham nesse assunto, em face dêsse fato, são levados a minimizar a importância do hemograma como recurso diagnóstico das helmintoses e a nāo o considerarem útil para a avaliação do prognóstico de algumas delas, particularmente da estrongiloidose.

Esse assunto merece cuidadoso estudo crítico, não só no pertinente ao seu sig.nificado semiológico, bem como nos aspectos doutrinários a serem apreciados na compreensão da patologia das helmintoses.

A maioria dos autores de obras básicas de parasitologia médica afirma que nos casos crônicos de verminoses não se observa aumento das taxas de eosinófilos no sangue, considerando-se esta ocorrência como traduzindo um grau de tolerância do organismo infestado às ações do parasito.
A curva de Lavier, já descrita anteriormente, e os dados de muitos outros investigadores dão validade a essa concepção, porém não explicam a fisiopatologia das eosinopenias e anesinofilias nos casos graves e algumas vêzes fatais de verminoses.

Com os dados de que dispomos e os de alguns pesquisadores, tentaremos construir uma hipótese para explicar, pelos menos em relação a alguns vermes intestinais, as causas de uma aneosinofilia ou eosinopenia, quer nos casos assintomáticos ou benignos, quer naqueles com sintomatologia grave e, não raro fatais, tal como ocorre na estrongiloidose.

Voltando a consultar a tabela $B$ dêsse trabalho, nota-se que, de 2.666 pessoas examinadas, 1.941 delas tiveram seus exames de fezes positivos para um ou mais helmintos e destas, $772(39,77 \%)$ não apresentam hipereosinofilias.

A pergunta que naturalmente surge é a seguinte: - Por que, sendo os vermes, de um modo geral, eosinofilogênicos, tantos indivíduos parasitados não apresentam eosinofilias sanguineas acima de $5 \%$ ?

A resposta a essa pergunta é bem mais trabalhosa que a da situação contrária, na qual se cogitava de saber porque dentre os casos com exames coprológicos negativos, $37,10 \%$ dêles apresentavam hipereosinofilia (Tabela $B$ ).

Alinharemos a seguir os itens de nossa hipótese que na falta de dados experimentais é erigida com fundamento na observação de casos clínicos de infestação verminótica.

a) - Nas fases avançadas, crônicas, de parasitismo não complicado por afecções intercorrentes há, via de regra, tendência à normalização da eosinofilia sanguínea, sendo $o$ fator cronológico o único atuante no estabelecimento do equilíbrio biológico entre dois sêres antagonistas, o parasito e o hospedeiro. Nestes casos a infestação é inaparente e muitas vêzes assintomática, qualquer que seja o helminto em causa.

b) - As eosinofilias normais, as hipereosinofilias $\mathrm{e}$ as aneosinofilias podem ser observadas nos casos de parasitismo por diversos vermes, quer isoladamente, quer em in- 
festações múltiplas. (Tabelas $\mathbf{C}$ D, E e F.)

c) - O número de casos sem hipereosinofilia cresce à proporção em que diminuem os índices eosinofilicos de cada um dos parasitos e das suas associaçôes. As tabelas $\mathrm{G}, \mathrm{H}, \mathrm{I}$ e $\mathrm{J}$, indicam claramente o fato; assim, na associação $N e$ cator-Trichuris-Strongyloides, de índice eosinofílico 6,89 , apenas $12,66 \%$ dos casos não têm hipereosinofilia, enquanto no parasitismo pelo Trichuris isoladamente, de I.Eo $=0,67,59,65 \%$ têm taxas de eosinófilos abaixo de $5 \%$.

d) - Nos casos de parasitismo pelo Strongyloides e em tôdas as associações em que um dos associados è êste nematódeo, diminui o número de casos sem hipereosinofilia, conforme se nota na ordenação da Tabela M.

Nota-se nesta ordenação que a associação Trichuris-Strongyloides ocupa a zona limitrofe entre o tipo de parasitismo em que está presente o Strongyloides com índices eosinofílicos crescentes e o em que êste é ausente com índices cada vez mais baixos.

Coincidência que chama a atenção na citada ordenação é a associação de Trichuris-Strongyloides, na qual o primeiro dos nematódeos aqui considerados é o menos eosinofilogênico e o segundo, o mais eosinofilogênico de todos os vermes.

e) - Para os nematódeos em estudo, o número de exemplares de cada um dêles, inferido pelo número de ovos encontrados nas fezes, influencia em proporção direta a eosinofilia; tanto menor o número de exemplares quanto maior a possibilidade de serem observadas eosinofilias baixas.

Infelizmente não podemos oferecer aqui dados numéricos relativos a esta asserção, baseada que foi na observação de reduzido número de casos em pesquisa paralela a esta.

Para o Strongyloides o número de larvas encontradas nas fezes não têm re- lação com a eosinofilia e é quase impossível estabelecer-se a relação do número de larvas com o das fêmeas partenogenéticas parasitas, podendo haver casos em que baixas eosinofilias coincidem com grande número de larvas nas fezes e, vice-versa, grandes hipereosinofilias em casos em que a pesquisa pelo método de Baermann não revela senão uma larva.

f) - Nas infestações crônicas pelos ancilostomídeos e Ascaris em periodo muito afastado da fase pulmonar, pré-intestinal, há tendência a aụ mentar o número de casos com eosinofilias normais, fato observado na maior parte dos nossos casos, principalmente dentre os operários da Petrobrás de padrão econômico bom e sujeitos à vigilância médica. Nas infestações crônicas pelo Strongyloides, as eosinofilias baixas são menos freqüentes em virtude da possibilidade de ocorrer a autoinfestaçāo interna, que condiciona o aumento da taxa dos eosinófilos no sangue, fato êste para o qual Arantes Pereira (1) chamou a atenção em seu estudo monográfico sôbre a estrongiloidose.

g) - Fator não menos importante para condicionar a redução do número de eosinófilos circulantes nas infestações helmínticas são as infecções, nas quais o "fator séptico de Simon" provocaria uma "eosinopenia de alarme". Essa eventualidade foi lembrada por Deschiens (15) e Arantes Pereira (1).

h) - Outros fatôres eosinopeniantes que podem intervir'no hemograma dos indivíduos infestados por vermes, diminuindo a eosinofilia, são certos medicamentes como o salicilato de sódio (11); a cortisona e o ACTH, o éter, os barbitúricos, a uretana, os anti-histamínicos e outros (15). Muitos dos medicamentos usuais poderiam reduzir a taxa de eosinófilos sanguíneos em indivíduos parasitados por vermes. devendo esta eventualidade ser lembrada na interpretação dos hemogramas no estudo dos casos clínicos. 
i) - As eosinofilias sanguíneas são dependentes da capacidade reacional do organismo e é evidente que, constitucionalmente, os reatores fracos darão respostas eosinofílicas leves à ação das substâncias elaboradas pelo parasito que agem sôbre o sistema eosinofilogênico. Nesse caso, os fatos deverão ser análogos ao que se observa num grupo de pessoas igualmente sujeitas às mesmas substâncias sensibilizadoras e que oferecem respostas de intensidades muito variáveis ou mesmo nem reagem. Corroborando essa hipótese, lembramos que nem tôdas as pessoas infestadas pela Wuchereria bancrofti, pelo Schistosoma mansoni e pelo Strongyloides stercoralis reagem igualmente às reaçōes intradérmicas com os respectivos antígenos. Ofereço essa última argumentação baseado no fato de que as substâncias elaboradas no corpo dos vermes parasitos são consideradas de natureza tóxica e ao mesmo tempo alergisante.

j) - Por fim chegamos ao ponto mais importante do problema que é o do esclarecimento da existência de casos graves de verminose, em particular da estrongiloidose, em que nāo há hipereosinofilia ou faltam completamente mesmo os eosinófilos no sangue periférico.

Se para os casos benignos ou assintomáticos, as eosinofilias normais, as hipoeosinofilias e mesmo as aneosinofilias traduzem tolerância do hospedeiro ao parasitismo por vermes, para os casos graves outra explicação deve ser tentada. Aliás, nas duas situações devemos ter em mente o fato de que o hemograma revela apenas uma fase transitória no processo dinâmico que se estende da formação, amadurecimento e libertação dos leucócitos, e, no caso os eosinófilos, que atingem os tecidos onde preenchem seu papel fisiológico após uma fase sanguícola transitória e efêmera .

Nos casos benignos representados por simples portadores de vermes, nos quais a taxa de eosinófilos no hemozrama é menor que cinco, seria razoável pensar nu- ma situação de eosinopoiese em equilíbrio, ainda que instável, sujeito a ser rompido, na dependência de modificações biológicas a que podem estar sujeitos os dois têrmos da associação parasito-hospedeiro.

Mas, que dizer das eosinopenias e aneosinofilias dos casos graves e algumas vêzes fatais de estrongiloidose?

Com os dados de nossas pesquisas não podemos criar uma hipótese para tentar responder a essa questão, porque a maioria dos casos por nós estudados eram benignos, em se tratando de pessoas adultas, pelo menos com saúde para exercer suas atividades, como operários. Nesses casos a inexistência de hipereosinofilia deveria corresponder àquele equilíbrio eosinopoiético a que há poucos nos referimos. Valer-nos-emos, portanto, dos resultados de outros pesquisadores que trabalharam com casos graves, alguns dêles estudados em vida e "post-mortem".

Para se compreender êsse fenômeno aparentemente paradoxal, devemos relembrar, se bem que de modo conciso, a fisiologia da eosinopoiese.

Sob muitos aspectos está razoàvelmente estabelecido o mecanismo fisiológico do sistema hipófiso-córtico-supra-renal na produção e mobilização dos eosinófilos e suas implicações nas reaçōes biológicas antígeno-anticorpo, bem como na liberação da histamina e outras substâncias como a heparina (2) .

Aspecto particular dêsse mecanismo é a estreita relação entre os eosinófilos e mastócitos nas doenças alérgicas, bem como nas helmintoses, observando-se nelas coexistência de hipereosinofilia e hipermastocitose (22), como a indicar uma correlação interdependente na atividade daquelas células.

Há alguns dados experimentais e outros obtidos de observações que poderão servir como subsídios para explicar a eosinopenia ou a aneosinofilia nos casos graves de helmintoses.

1..$^{\circ}$ - A inoculação de 30 cercárias de Schistosoma mansoni, por Fernex, em camundongos, de uma única vez, provocou uma diminuição da taxa de eosinófilos que atingiu em sete dias seus valôres mais baixos para, então, se elevar gradualmente. Como complemento a esta experiência foram feitos em outros animais quatro ino- 
culações de 15 cercárias, uma inoculação por semana, observando-se uma ascensão dos eosinófilos no sangue que atingiu o máximo alguns dias após a última inoculação, para daí em diante, cair gradualmente.

A introdução abrupta de 30 cercárias no camundongo, produz, em virtude das suas substâncias tóxicas ou sensibilizadoras, liberação de histamina nos tecidos, em conseqüência da degranulação dos mastócitos, provocando imediato afluxo dos eosinófilos para exercer aí sua função anti-histamínica.

Em decorrência dêsse fato aparece, de chôfre, uma eosinopenia que é sucedida, após algum tempo, por uma eosinofilia normal.

2.0 - A experiência citada guarda paralelismo com as de Weinberg e Seguin, em 1914 (51). Weinberg e Seguin mostraram que a injeção de extrato de Ascaris produz no tecido conjuntivo subconjuntival do cavalo um enantema e um edema acentuado, com afluxo de eosinófilos para o local.

3. ${ }^{\circ}$ - Riley (44) observou após uma reação anafilática experimental em cobaio, nos cornetos do nariz, uma degranulação generalizada dos mastócitos, acarretando, de imediato, um maciço infiltrado de eosinófilos. Algumas semanas mais tarde os mastócitos reapareceram lentamente e atingiram números normais.

Sabe-se que os extratos de helmintos, tanto quanto as substâncias que êles secretam, são mastocitóxicas e liberadoras de histamina (45).

4..$^{\circ}$ - Em uma experiência de Fernex (loc. cit.), onze camundongos foram infestados três vêzes, com intervalos de 15 dias por 30 cercárias de Schistosoma mansoni. Ao término de três meses os animais foram sacrificados e em fragmentos da pele da regiāo ventral foi feita a contagem dos mastócitos, que foi três vêzes superior à observada nos animais testemunha. Esta experiência, analisađa em confronto com as anteriores, mostra a estreita correlação entre eosinófilos e mastócitos, os quais formam o sistema celular eosinofílico-mastocitário.
5. - E fato conhecido que os eosinófilos desaparecem da mucosa digestiva em conseqüência de um jejum prolongado ou mais precisamente, num regime de carência protêica (2). Em adição a êsse fato, segundo dados do mesmo autor, a cessação do afluxo de eosinófilos para o tubo digestivo parece ser a causa principal da parada da eosinopoiese medular, da qual decorre uma eosinopenia sanguínea comparável à observada nas carências protêicas.

6. - A análise da casuística de Machado da Silva (35) sôbre estrongiloidose nos revela a coexistência em todos os indivíduos estudados, de diarréia, vômitos, hipoproteinemia e aenosinofilia ou hipoeosinofilia. Acredito que a hipoproteinemia nesses casos seja resultado não só de má absorção intestinal, como da diarréia e vômitos, estabelecendo-se uma carência alimentar semelhante à da carência protêica obtida experimentalmente em ratos, por Aschkenasy, em 1962 (2).

7..$^{\circ}$ - Os estudos de Deschiens, Poirier e Lamy (20) comentados por Deschiens (15) sôbre a histopatologia da supra-renal de cobaias tratadas por extratos de Fasciola hepática evidenciam "alterations profondes dégénératives de l'assise réticulée, correspondant à une hipertrophie hipofonctionelle inflamatoire et necrotique de la glande".

Desta verificação é possível se deduzir que a deficiência hormonal resultante do dano da supra-renal provocaria inicialmente $\overline{\mathrm{um}}$ aumento dos eosinófilos e secundàriamente uma eosinopenia por esgotamento do sistema mastocitário e eosinopoiético.

Nossa hipótese se baseia no fato de que os glucocorticosteróides de ação antagônica à histamina, pelo fato de estarem diminuídos, em virtude dos processos degenerativos da supra-renal, deixam livre a histamina resultante da degranulação dos mastócitos, a qual num certo periodo aceleraria a eosinopoiese e, em seguida, produziria o esgotamento da medula óssea, com conseqüente eosinopenia ou aneosinofilia. Os esquemas seguintes mostram, sob a forma de hipóteses, o andamento dos fenômenos aqui considerados. 


\title{
HIPÓTESE PARA EXPLICAR A EOSINOPENIA
}

\section{NOS CASOS GRAVES DE ESTRONGILOIDOSE}

ESQUEMA "A"

\author{
Primeira fose (HIPERREATIVA)
}

AÇÃo dAs SUBSTÁNCIAS ELABORAdAs PELO VERME

MASTÓCITOS

(LIBERAÇĀO
SOBRE

CÁPSULA SUPRA-RENAL

LDEPLECĀO DOS CORTICOSTEROIDE!

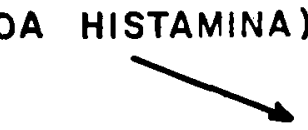

ATIVAÇÃo dA EOSINOPOIESE dA MEDULA ÓSSEA

HIPEREOSINOFILIA SANGUINEA

\section{Segunda fase}

PERSISTÊNCIA DA AÇĀO DAS
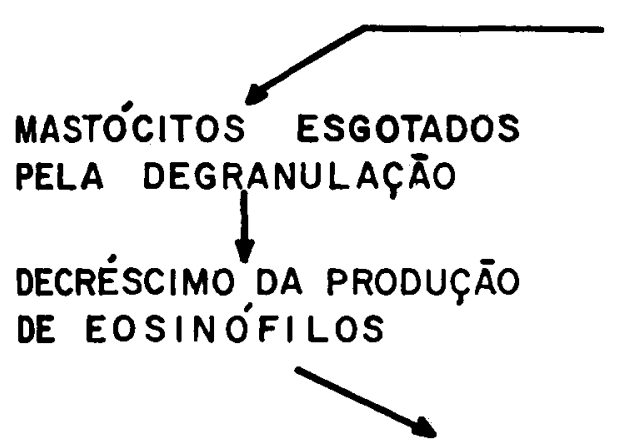

EOSINOPENIA
(HIPORREATIVA) SÔBRE

CÁPSULAS SUPRA-RENAIS LESADAS (DEPLEÇĀO DOS CORTICOSTERÓIDES)

FADIGA DA MEDULA ÓSSEA PARA PRODUÇĀO DE EOSINÓFILOS
A análise dos dados que acabamos de expor nos tópicos anteriores permite-nos compreender, embora em caráter presuntivo, o modo pelo qual em algumas helmintoses, ao invés da hipereosinofilia, observa-se eosinopenia ou mesmo aenosinofilia.

Baseando-nos nas experiências em cobaios e no cavalo, acima referidas, chegamos à conclusão de que há estreita relação entre os eosinófilos e mastócitos, os quais, tal como já assinalamos, constituem um sistema de atividade conjugada. Os mastócitos teciduais, respondendo à agressão dos produtos formados pelos vermes parasitos reagem degranulando-se e dêsse modo libertam a histamina, a qual, por sua ação eosinostática, provoca o afluxo dos eosinófilos para os tecidos onde desempenham sua atividade anti-histamínica.

Decorre dessa contingência uma transitória eosinopenia sanguinea, a qual é subseqüentemente substituida por uma eosinofilia normal ou uma hipereosinofilia 
ESQUEMA "B"

Primeira fase

(HIPERREATIVA)

PAREDE INTESTINAL PARASITADA PELO STRONGYLOIDES (DEGRADAÇĀO DAS PROTEINAS ALIMENTARES NORMAL E LIBERAÇĀO DAS MISTAMINAS AO NIVEL DO INTESTINO)<smiles>CCOC</smiles>

AFLUXO DOS EOSINÓFILOS PARA A PAREDE INTESTINAL EM DECORRÊNCIA DO PARASITISMO E DA DEGRADAÇÃO

DAS PROTEINAS ALIMENTARES

ATIVAÇĀO DA EOSINOPOIESE

DA MEDULA ÓSSEA

HIPEREOSINOFILIA

Segunda fase

(HIPORREATIVA)

PAREDE INTESTINAL LESADA PELO STRONGYLOIDES (DEGRADAÇÄO DAS PROTEINAS ALIMENTARES REDUZIOA)

\author{
REDUÇÃO DOS EOSINÓFILOS NA \\ PAREDE INTESTINAL
}

DESESTÍMULO DA EOSINOPOIESE DA MEDULA ÓSSEA POF DIMINUIÇĀO DA DEMANDA DE EOSINÓFILOS PARA 0 INTESTINO

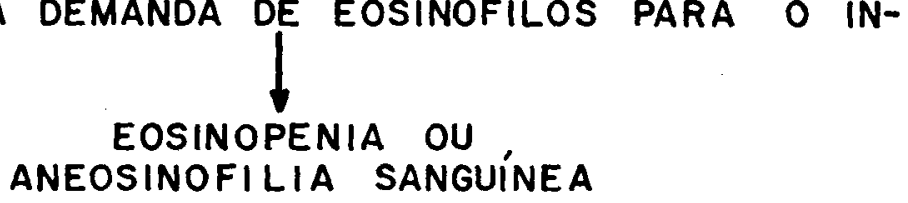

por hiperatividade da medula óssea. possível que nos processos de agudização, como sucede na estrongiloidose, em decorrência da autoinfestação, apareça uma eosinopenia transitoria em virtude da mobilização dos eosinófilos para as áreas lesadas, eosinopenia esta sucedida nos casos de reação favorável por eosinofịlias normais ou altas, ou ao contrário, duradoura, quando há falência na defesa imunitária.

Arantes Pereira (1) chama a atenção para o aumento das eosinofilias, tanto nos casos não tratados quanto nos tratados, indicando que à cura da doença segue-se, inicialmente, hipereosinofilia e só depois normalização da taxa de eosinófilos no sangue. Essa verificação indica aumento das substâncias libertadas pelos vermes mortos agindo sôbre os mastócitos, provocando no início eosinopenia sanguínea, logo a seguir, hipereosinofilia e só ulteriormente, a prazo mais longo, a normalização da taxa de eosinófilos. $\mathrm{Na}$ investigação de Arantes, tanto nos casos com eosinopenia quanto nos com hipereosinofilia que 


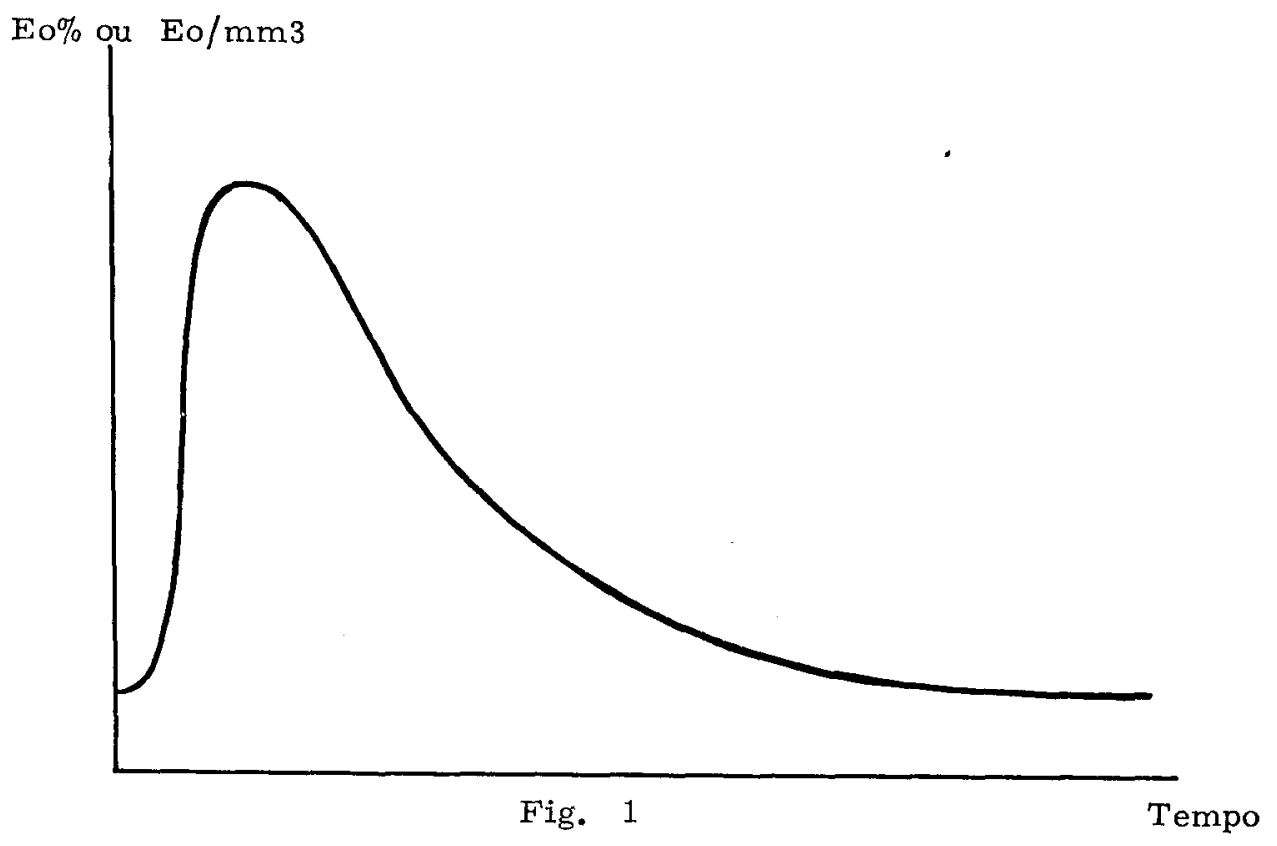

Curva eosinofílica das helmintoses segundo Lavier

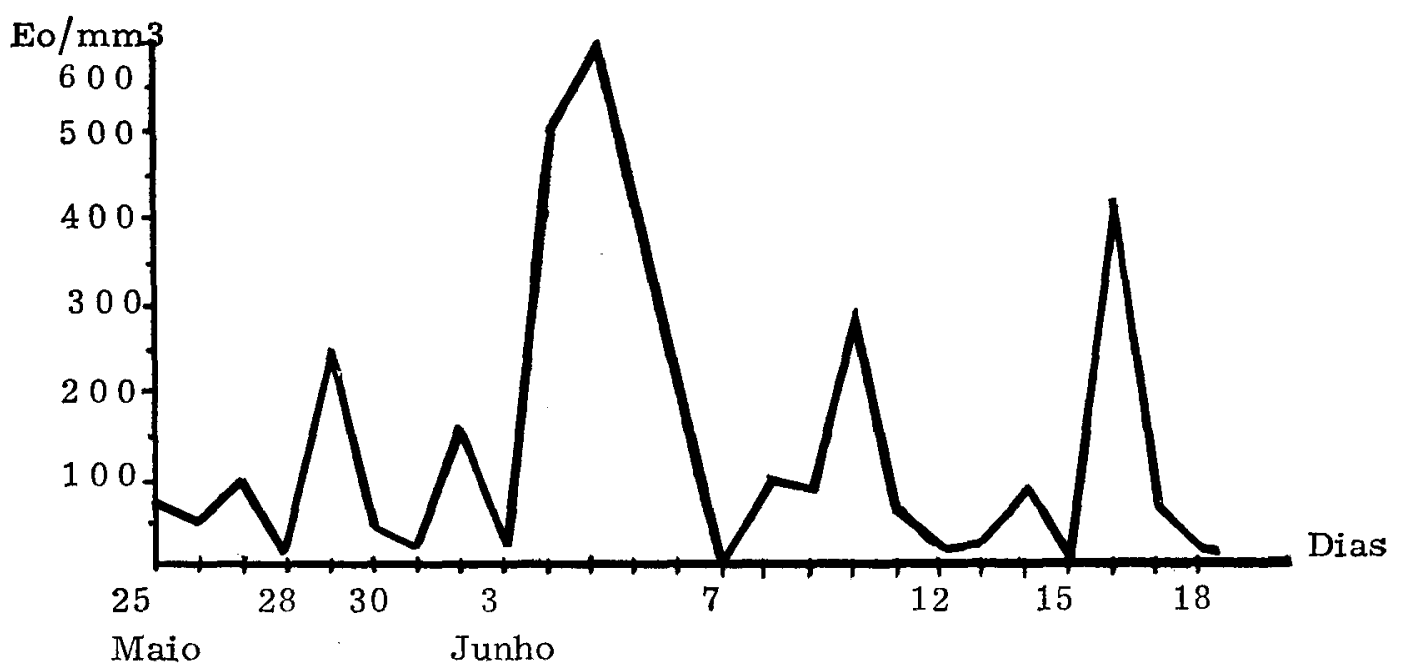

Fig. 2

Curva eosinofílica de um asmático segundo Coste, Delbarre, Laurent e Lachronique 
TABELA A

NÚMERO DE VÊZES EM QUE FORAM ENCONTRADOS OS HELMINTOS EM 2.666 PESSOAS.

\begin{tabular}{lcc}
\hline ASCARIS LUMBRICOIDES & 547 & $(20,51 \%)$ \\
NECATOR AMERICANUS & 599 & $(22,46 \%)$ \\
TRICHURIS TRICHIURA & 1248 & $(46,81 \%)$ \\
STRONGYLOIOES STERCORALIS & 636 & $(23,85 \%)$ \\
ENTEROBIUS VERMICULARIS & 18 & $(0,67 \%)$ \\
SCHISTOSOMA MANSONI & 44 & $(1,65 \%)$ \\
TAENIA SP & 7 & $(0,26 \%)$ \\
HYMENOLEPIS NANA & 3 & $(0,11 \%)$ \\
\hline
\end{tabular}

TABELA B

PESSOAS EXAMINADAS: 2.666

DISTRIBUIÇÃO dOS CASOS POSITIYOS E NEGATIVOS PELLOS GRUPOS DE EOSINOFILIAS

\begin{tabular}{|c|c|c|c|c|c|c|c|}
\hline & Eo $\%$ & $\begin{array}{ccc}1 & 0 & 4 \\
E & 0 & \%\end{array}$ & $\begin{array}{lll}5 & 0 & 9 \\
E & 0 & \%\end{array}$ & $\begin{array}{c}10 \text { a } 18 \\
E 0 \%\end{array}$ & $\begin{array}{l}>19 \\
E_{0} \%\end{array}$ & EO $<5 \%$ & $E 0>5 \%$ \\
\hline $\begin{array}{c}1941 \\
\text { CASOS POSITIVOS }\end{array}$ & $\begin{array}{c}45 \\
(2,31 \%)\end{array}$ & $\begin{array}{c}727 \\
(37,45 \%)\end{array}$ & $\begin{array}{c}611 \\
(31,47 \%)\end{array}$ & $\begin{array}{c}435 \\
(22,41 \%)\end{array}$ & $\begin{array}{l}123 \\
(6,33 \%)\end{array}$ & $\begin{array}{c}772 \\
(39,77 \%)\end{array}$ & $\begin{array}{c}1169 \\
(60,22 \%)\end{array}$ \\
\hline $\begin{array}{c}725 \\
\text { CASOS NEGATIVOS }\end{array}$ & $\begin{array}{c}38 \\
(5,24 \%)\end{array}$ & $\begin{array}{c}418 \\
(57,65 \%)\end{array}$ & $\begin{array}{c}177 \\
(24,44 \%)\end{array}$ & $\begin{array}{c}82 \\
(m, 31 \%)\end{array}$ & $\begin{array}{c}10 \\
(1,37 \%)\end{array}$ & $\begin{array}{c}456 \\
(62,89 \%)\end{array}$ & $\begin{array}{c}2.69 \\
(37,10 \%)\end{array}$ \\
\hline
\end{tabular}


TABELA $\underline{C}$ distribuição dos CASOS de PARASITISMO POR HELMINTOS ISOLAdOS PELOS gRAUS de EOSINOFILIA.

\begin{tabular}{|c|c|c|c|c|c|c|}
\hline . & $\begin{array}{c}0 \\
E 0 \%\end{array}$ & $\begin{array}{l}\text { I } \\
\text { E } 0 \% \\
\end{array}$ & $\begin{array}{c}5 \text { a } 9 \\
\text { E } 0 \%\end{array}$ & $\begin{array}{c}10 \text { a } 18 \\
E 0 \%\end{array}$ & $\begin{array}{l}>19 \\
E 0 \%\end{array}$ & TOTAL \\
\hline ASCARIS & $7(4,48 \%)$ & $75(48,07 \%)$ & $46(29,48 \%)$ & $24(15,38 \%)$ & $4(2,56 \%)$ & 156 \\
\hline NECATOR & $3(1,88 \%)$ & $54(33,96 \%)$ & $53(33,33 \%)$ & $42(26,41 \%)$ & $7(4,40 \%)$ & 159 \\
\hline TRICHURIS & $23(4,00 \%)$ & $320(55,65 \%)$ & $155(26,97 \%)$ & $70(12,17 \%)$ & $7(1,21 \%)$ & 575 \\
\hline STRONGYLOIDES & $2(1,23 \%)$ & $35(21,60 \%)$ & $53(32,71 \%)$ & $49(30,24 \%)$ & $23(14,19 \%)$ & 162 \\
\hline ENTEROBIUS & 0 & 6 & 3 & 1 & 0 & 10 \\
\hline SCHISTOSOMA & 0 & 2 & 4 & 2 & 0 & 8 \\
\hline TAENIA & 1 & 0 & 0 & 1 & 0 & 2 \\
\hline HYMENOLEPIS & 0 & 0 & 1 & 0 & 0 & 1 \\
\hline
\end{tabular}


TABELA D

distribuicão dos casos de parasitismo por doIs helmintos pelos graus de EOSINOFILIA.

\begin{tabular}{|c|c|c|c|c|c|c|}
\hline & E $0 \%$ & $\begin{array}{l}1 \text { E } \\
\text { E } 0 \%\end{array}$ & $5 \begin{array}{rr}0 & 9 \\
E & 0\end{array}$ & 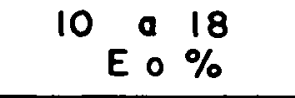 & $\begin{array}{l}>19 \\
E_{0} \%\end{array}$ & TOTAL \\
\hline ASCARIS + NECATOR & $0(0 \%)$ & $8(32,00 \%)$ & $7(28,00 \%)$ & $9(36,00 \%)$ & $1(4,00 \%)$ & 25 \\
\hline ASCARIS + TRICHURIS & $6(3,63 \%)$ & $71 \quad(43,03 \%)$ & $51(30,90 \%)$ & $25(15,15 \%)$ & $12(7,27 \%)$ & 165 \\
\hline ASCARIS + STRONGYLOIDES & $0(0 \%)$ & $6(18,75 \%)$ & $13(40,62 \%)$ & $9(28,12 \%)$ & $4(12,50 \%)$ & 32 \\
\hline ASCARIS + ENTEROBIUS & 0 & 1 & 0 & 0 & 0 & 1 \\
\hline ASCARIS + SCHISTOSOMA & 0 & 1 & 3 & 0 & 0 & 4 \\
\hline NECATOR+ TRICHURIS & $2(1,62 \%)$ & $43(34,95 \%)$ & $37(30,08 \%)$ & $29(23,57 \%)$ & $12(9,75 \%)$ & 123 \\
\hline NECATOR + STRONGYLOIDES & $0(0 \%)$ & $13(13,40 \%)$ & $31(31,95 \%)$ & $40(41,23 \%)$ & $13(13,40 \%)$ & 97 \\
\hline NECATOR+ SCHISTOSOMA & 0 & 2 & 0 & 1 & 0 & 3 \\
\hline NECATOR + HYMENOLEPIS & 0 & 0 & 1 & 0 & 0 & 1 \\
\hline TRICHURIS + STRONGYLOID. & $0(0 \%)$ & $39(25,00 \%)$ & $57(36,53 \%)$ & $48(30,76 \%)$ & $12(7,69 \%)$ & 156 \\
\hline TRICHURIS + ENTEROBIUS & 0 & 1 & 0 & 0 & 0 & 1 \\
\hline TRICHURIS + SCHISTOSOMA & 0 & 1 & 2 & 1 & 0 & 4 \\
\hline TRICHURIS + TAENIA & 0 & 2 & 0 & 1 & 0 & 3 \\
\hline STRONGYLOIDES + SCHIST. & 0 & 0 & 2 & 0 & 0 & 2 \\
\hline
\end{tabular}


TABELA E

DISTRIBUIÇ̃̃o dOS CASOS DE PARASITISMO POR TRÊS HELMINTOS PELOS gRAUS de EOSINOFILIA.

\begin{tabular}{|c|c|c|c|c|c|c|}
\hline & $\begin{array}{c}0 \\
E 0 \%\end{array}$ & $\begin{array}{rrr}1 & 0 & 4 \\
E & 0 \%\end{array}$ & $\begin{array}{l}5 \text { O } 9 \\
E 0 \%\end{array}$ & $\begin{array}{c}10018 \\
E 0 \%\end{array}$ & $\begin{array}{r}>19 \\
E 0 \%\end{array}$ & TOTAL \\
\hline ASCARIS + NECATOR + TRICHURIS & $1(2,08 \%)$ & $12(25,00 \%)$ & $18(37,50 \%)$ & $15(31,25 \%)$ & $2(4,16 \%)$ & 48 \\
\hline ASCARIS + NECATOR + STRONGYLOIDES & $0(0 \%)$ & $5(19,23 \%)$ & $9(34,61 \%)$ & $7(26,92 \%)$ & $5(19,23 \%)$ & 26 \\
\hline ASCARIS + TRICHURIS + STRONGYLOIDES & $0(0 \%)$ & $11(23,91 \%)$ & $16(34,78 \%)$ & $14(30,43 \%)$ & $5(10,86 \%)$ & 46 \\
\hline ASCARIS + TRICHURIS + ENTEROBIUS & 0 & 2 & 2 & 0 & 0 & 4 \\
\hline ASCARIS + TRICHURIS+ SCHISTOSOMA & 0 & 1 & 0 & 2 & 0 & 3 \\
\hline ASCARIS + TRICHURIS + HYMENOLEPIS & 0 & 0 & 1 & 0 & 0 & 1 \\
\hline ASCARIS + STRONGYLOIDES + SCHISTOSOMA & 0 & । & 0 & 0 & 0 & 1 \\
\hline NECATOR + TRICHURIS + STRONGYLOIDES & 0 & $9(12,67 \%)$ & $28(39,43 \%)$ & $24(33,80 \%)$ & $10(14,08 \%)$ & 71 \\
\hline NECATOR + TRICHURIS + SCHISTOSOMA & 0 & 1 & 1 & 3 & 0 & 5 \\
\hline NECATOR+STRONGYLOIDES+SCHISTOSOMA & 0 & 0 & 1 & 1 & 0 & 2 \\
\hline TRICHURIS + STRONGYLOIDES + ENTEROBIUS & 0 & 0 & 1 & 0 & 0 & 1 \\
\hline TRICHURIS + STRONGYLOIDES + SCHISTOSOMA & 0 & 0 & 0 & 1 & 1 & 2 \\
\hline TRICHURIS + STRONGYLOIDES + TAENIA & 0 & 1 & 0 & 0 & 0 & 1 \\
\hline TRICHURIS + ENTEROBIUS + SCHISTOSOMA & 0 & 0 & 0 & 1 & 0 & 1 \\
\hline
\end{tabular}


TABELA E

DISTRIBUIÇÃo dOS CASOS DE PARASITISMO POR QUATRO E CINCO HELMINTOS PELOS gRAUS de EOSINOFILIA.

\begin{tabular}{|c|c|c|c|c|c|c|}
\hline & $\begin{array}{c}0 \\
E 0 \%\end{array}$ & $\begin{array}{c}104 \\
E 0 \%\end{array}$ & $\begin{array}{l}5 \text { a } 9 \\
\text { Eo\% }\end{array}$ & $\begin{array}{c}10 \text { a } 18 \\
E 0 \%\end{array}$ & $\begin{array}{r}19 \\
E 0 \%\end{array}$ & TOTAL \\
\hline ASCARIS + NECATOR + TRICHURIS + STRONGYLOIDES & $0(0 \%)$ & $4(13,79 \%)$ & $11(37,93 \%)$ & $11(37,93 \%)$ & $3(10,34 \%)$ & 29 \\
\hline ASCARIS + NECATOR + TRICHURIS + SCHISTOSOMA & 0 & 0 & 0 & 1 & 0 & 1 \\
\hline ASCARIS + NECATOR + TRICHURIS + TAENIA & 0 & 0 & 1 & 0 & 0 & । \\
\hline ASCARIS + NECATOR + STRONGYLOIDES + SCHISTOSOMA & 0 & 0 & 1 & 0 & 0 & 1 \\
\hline NECATOR + TRICHURIS + STRONGYLOIDES + SCHISTOSOMA & 0 & 0 & 0 & 2 & 2 & 4 \\
\hline $\begin{array}{l}\text { ASCARIS + NECATOR + TRICHURIS + STRONGYLOIDES } \\
\text { + SCHISTOSOMA }\end{array}$ & 0 & 0 & 2 & 1 & 0 & 3 \\
\hline
\end{tabular}


TABELA $\underline{G}$

\section{MONOPARASITISMO}

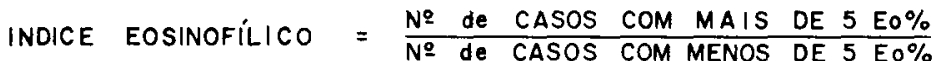

\begin{tabular}{l|c|c|c}
\hline & $\begin{array}{c}\text { No de cosos } \\
\text { com mais de } \\
5 \text { E } \% \%\end{array}$ & $\begin{array}{c}N=\text { de cosos } \\
\text { com menos } \\
\text { de E0 } \%\end{array}$ & $\begin{array}{c}\text { Indice } \\
\text { eosinofílico }\end{array}$ \\
\hline STRONGYLOIDES & $77,16 \%$ & $22,83 \%$ & $3,37 \%$ \\
NECATOR & $64,15 \%$ & $35,84 \%$ & $1,78 \%$ \\
ASCARIS & $47,43 \%$ & $52,56 \%$ & $0,90 \%$ \\
TRICHURIS & $40,34 \%$ & $59,65 \%$ & $0,67 \%$ \\
\hline
\end{tabular}

\section{TABELA}

ASSOCIAÇAO DUPLA

INDICE EOSINOFÍLICO = NO de CASOS COM MAIS DE 5 EO\%

\begin{tabular}{l|c|c|c}
\hline & $\begin{array}{l}\text { No de cosos } \\
\text { com mois de } \\
5 \text { E0\% }\end{array}$ & $\begin{array}{l}\text { No de cosos } \\
\text { com menos } \\
\text { de } 5 \text { E. } \%\end{array}$ & $\begin{array}{c}\text { Indice } \\
\text { eosinotílico }\end{array}$ \\
\hline NECATOR - STRONGYLOIDES & $86,59 \%$ & $13,40 \%$ & $6,46 \%$ \\
ASCARIS - STRONGYLOIDES & $81,25 \%$ & $18,74 \%$ & $4,33 \%$ \\
TRICHURIS - STRONGYLOIDES & $75,00 \%$ & $25,00 \%$ & $3,00 \%$ \\
ASCARIS - NECATOR & $68,00 \%$ & $32,00 \%$ & $2,12 \%$ \\
NECATOR - TRICHURIS & $63,41 \%$ & $36,58 \%$ & $1,70 \%$ \\
ASCARIS - TRICHURIS & $53,33 \%$ & $46,66 \%$ & $1,14 \%$ \\
\hline
\end{tabular}

\section{TABELA I}

ASSOCIAÇAO TRIPLA

INDICE EOSINOFILICO

$\begin{array}{lllllll}\text { Ne de } & \text { CASOS } & \text { COM MAIS } & \text { DE } 5 & \text { E. } \% \\ \text { NE de } & \text { CASOS } & \text { COM MENOS DE } 5 & \text { E0\% }\end{array}$

\begin{tabular}{l|c|c|c}
\hline & $\begin{array}{c}\text { Ne de cosos } \\
\text { com mais de } \\
5 \text { Eo } \%\end{array}$ & $\begin{array}{l}\text { No de cosos } \\
\text { com menos } \\
\text { de } 5 \text { E } 0 \%\end{array}$ & $\begin{array}{c}\text { Indice } \\
\text { eosinofílico }\end{array}$ \\
\hline NECATOR - TRICHURIS - STRONGYLOIDES & $87,33 \%$ & $12,66 \%$ & $6,89 \%$ \\
ASCARIS - NECATOR - STRONGYLOIDES & $80,76 \%$ & $19,23 \%$ & $4,08 \%$ \\
ASCARIS - TRICHURIS - STRONGYLIDES & $76,08 \%$ & $23,91 \%$ & $3,18 \%$ \\
ASCARIS - NECATOR - TRICHURIS & $72,91 \%$ & $27,08 \%$ & $2,69 \%$ \\
\hline
\end{tabular}


TABELA $\underline{J}$

ASSOCIACÃO QUÁORUPLA

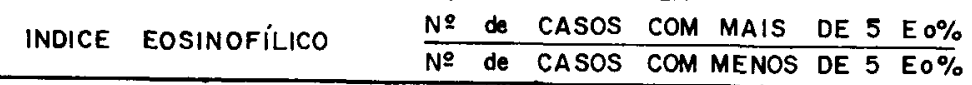

\begin{tabular}{l|c|c|c}
\hline & $\begin{array}{c}\text { No de cosos } \\
\text { com mais de } \\
5 \text { Eo\% }\end{array}$ & $\begin{array}{l}\text { No de cosos } \\
\text { com menos } \\
\text { de } 5 \mathrm{E} 0 \%\end{array}$ & $\begin{array}{c}\text { Indice } \\
\text { eosinofílico }\end{array}$ \\
\hline ASCARIS-NECATOR- TRICHURIS - STRONGYLIDES & $86,20 \%$ & $13,79 \%$ & $6,24 \%$ \\
\hline
\end{tabular}

TABELA $\underline{K}$

CASOS COM HIPEREOSINOFILIA NEGATIVOS PARA STRONGYLOIDES NO PRIMEIRO EXAME COPROLÓGICO E EM UMA OU DUAS REPETIÇŌES DÊSTE EXAME.

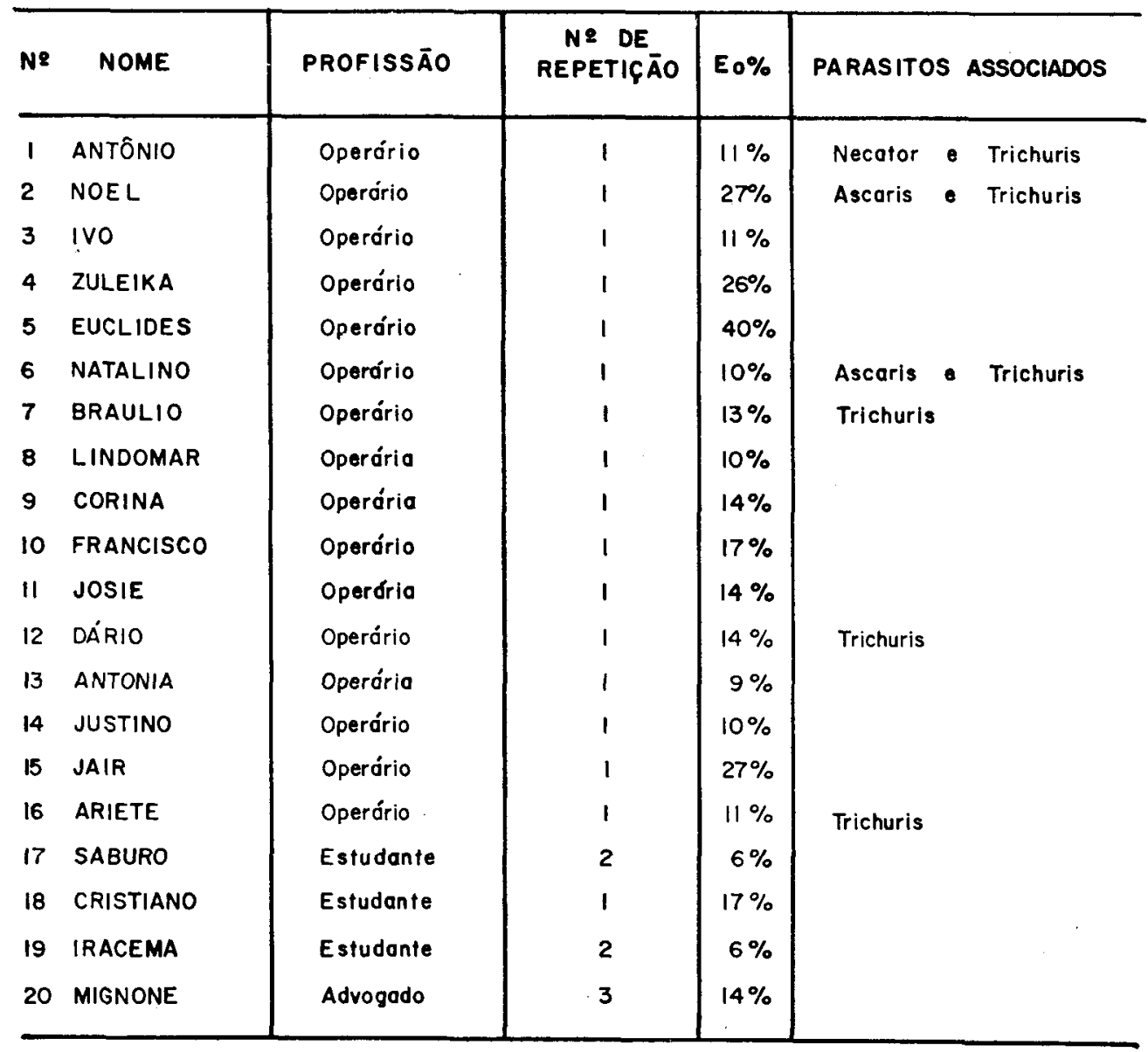


TABELA $\underline{\text { L }}$

CASOS COM HIPEREOSINOFILIA NEGATIVOS PARA STRONGYLOIDES NO PRIMEIRO EXAME COPROLÓGICO E POSITIVOS NOS SUBSEQUENTES.

\begin{tabular}{|c|c|c|c|c|c|}
\hline Ne & NOME & PROFISSĀO & $\begin{array}{c}\text { NE DE } \\
\text { REPETICAO }\end{array}$ & $E 0 \%$ & PARASITOS ASSOCIADOS \\
\hline 1 & AGUINALDO & Estudante & 1 & $14 \%$ & Necator \\
\hline 2 & MARLY & Estudante & 2 & $32 \%$ & \\
\hline 3 & JOSÉ MOTA & operório & 1 & $6 \%$ & Necator e Trichuris \\
\hline 4 & JOSÉ DE SOUZA & operório & 1 & $12 \%$ & Trichuris \\
\hline 5 & ROSA LEAL & Operória & 1 & $10 \%$ & \\
\hline 6 & ADNIR & Operário & 1 & $20 \%$ & \\
\hline 7 & JOSÉ FRANCISCO & Operário & 1 & $17 \%$ & Necolor \\
\hline 8 & MARIA SILVERIO & Operário & 1 & $10 \%$ & \\
\hline 9 & CHIAPPINE & Operório & 1 & $10 \%$ & \\
\hline 10 & ISABEL & Professôro & 4 & $18 \%$ & \\
\hline II & ALVARO & ESCOLAR & 4 & $37 \%$ & \\
\hline 12 & MALCINO & Operário & 2 & $34 \%$ & Ascoris Trichuris \\
\hline 13 & CARLOS ROBERTO & Estudante & 8 & $58 \%$ & \\
\hline 14 & GERALDA & LABORATORISTA & 4 & $14 \%$ & \\
\hline 15 & NELSON & Enfermeiro & 2 & $10 \%$ & \\
\hline 16 & MARCOS & Médico & i & $12 \%$ & \\
\hline 17 & MONJARDIM & Contodor & 3 & $9 \%$ & \\
\hline 18 & LAUDELINO & Estudante & 1 & $17 \%$ & \\
\hline 19 & NICOMEDES & Operório & 1 & $14 \%$ & \\
\hline 20 & JOĀO GUERRA & Operário & 1 & $7 \%$ & Necator - Trichuris \\
\hline
\end{tabular}


TABELA $\underline{M}$

$\begin{array}{ll}\text { NECATOR -TRICHURIS - STRONGYLOIDES } & 6,89 \\ \text { NECATOR - STRONGYLOIDES } & 6,46 \\ \text { ASCARIS - NECATOR - TRICHURIS - STRONGYLOIDES } & 6,24 \\ \text { ASCARIS - STRONGYLOIDES } & 4,33 \\ \text { ASCARIS - NECATOR-STRONGYLOIDES } & 4,08 \\ \text { STRONGYLOIDES } & 3,37 \\ \text { ASCARIS - TRICHURIS - STRONGYLOIDES } & 3,18 \\ \text { TRICHURIS - STRONGYLOIDES } & 3,00 \\ \text { ASCARIS - NECATOR-TRICHURIS } & 2,69 \\ \text { ASCARIS - NECATOR } & 2,12 \\ \text { NECATOR } & 1,78 \\ \text { NECATOR - TRICHURIS } & 1,70 \\ \text { ASCARIS - TRICHURIS } & 1,14 \\ \text { ASCARIS } & 0,90 \\ \text { TRICHURIS } & 0,67\end{array}$

ESCALONAMENTO DA CAPACIDADE EOSINOFILOGÊNICA NAS DIFERENTES MODALIDADES DE INFESTAÇĀO POR NEMATÓDEOS. 


\section{Gráfico 1 Tabela I}

$\%$ dos casos

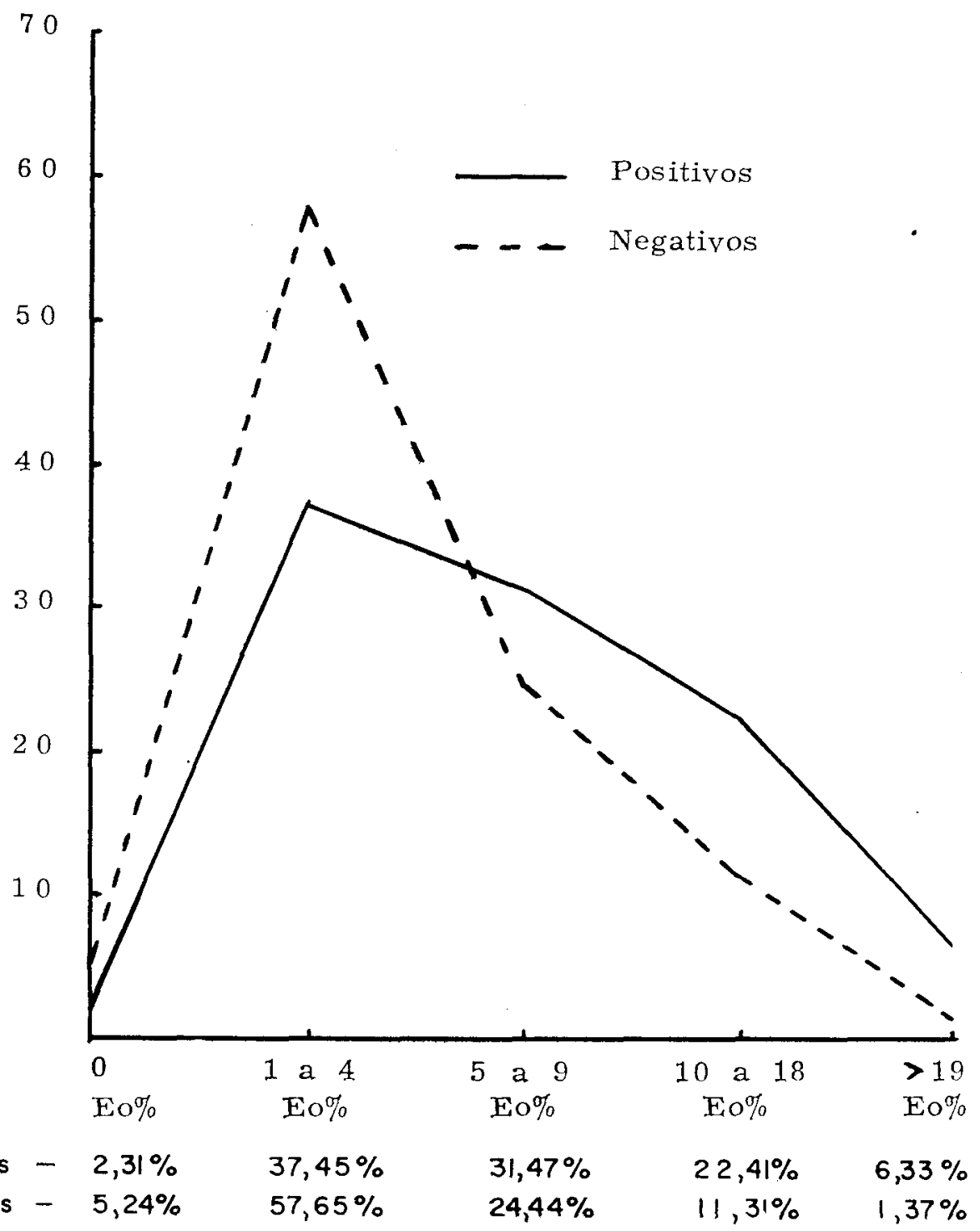

$\begin{array}{llllll}\text { Positivos - 2,31\% } & 37,45 \% & 31,47 \% & 22,41 \% & 6,33 \% \\ \text { Negotivos - 5,24\% } & 57,65 \% & 24,44 \% & 11,31 \% & 1,37 \%\end{array}$


Gráfico 2 Tabela II

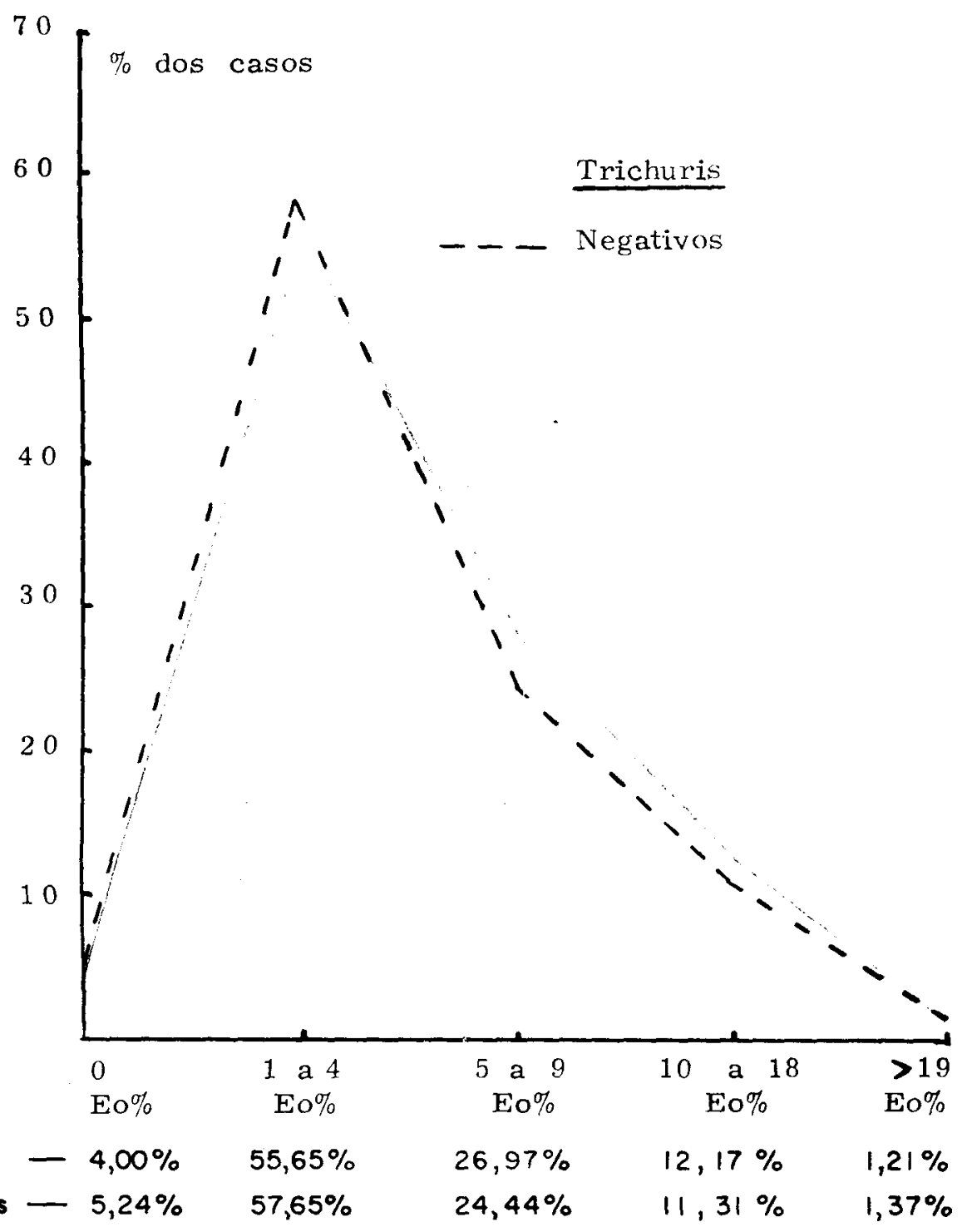


Gráfico $3 \quad$ Tabela III

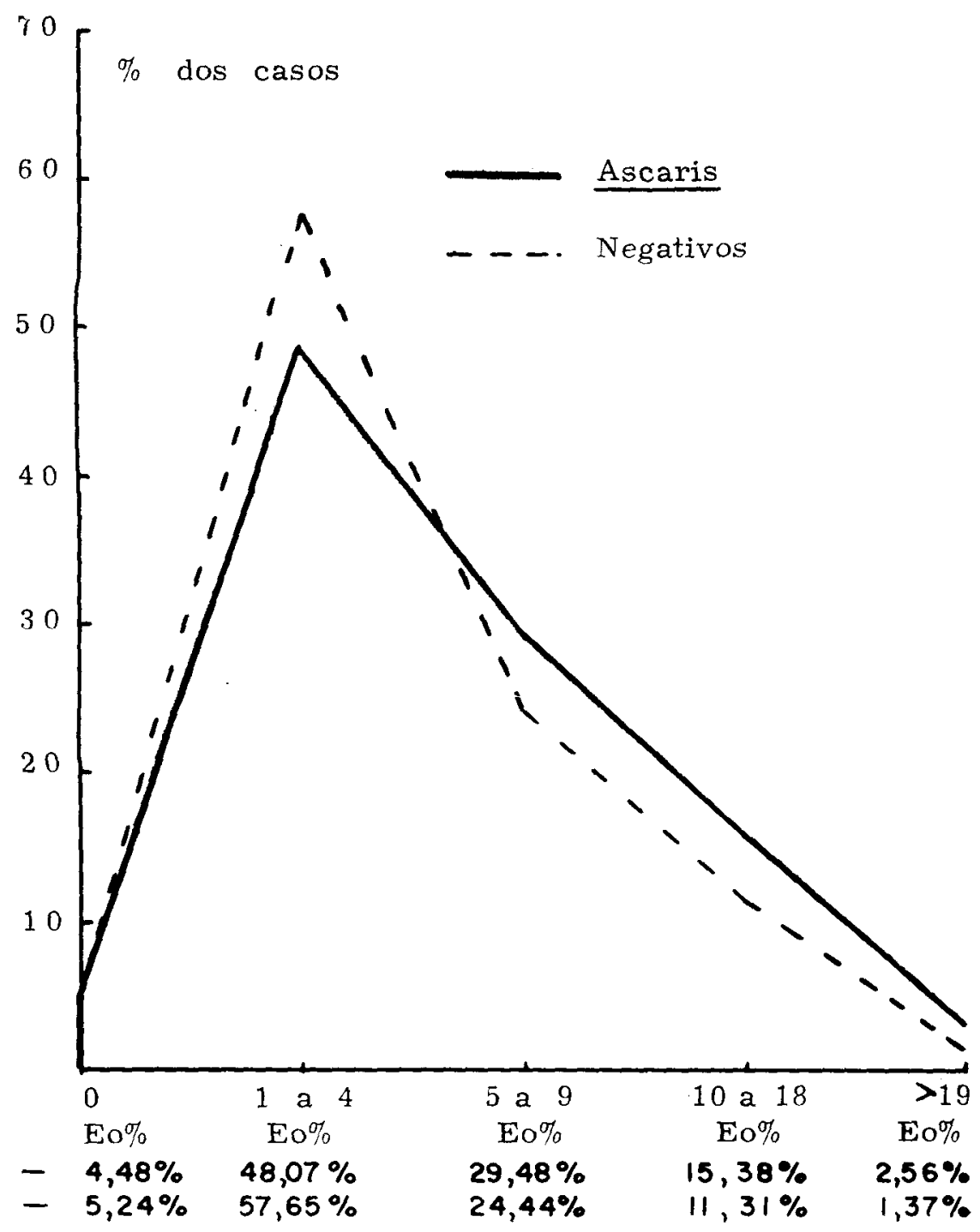


Gráfico 4 Tábela IV

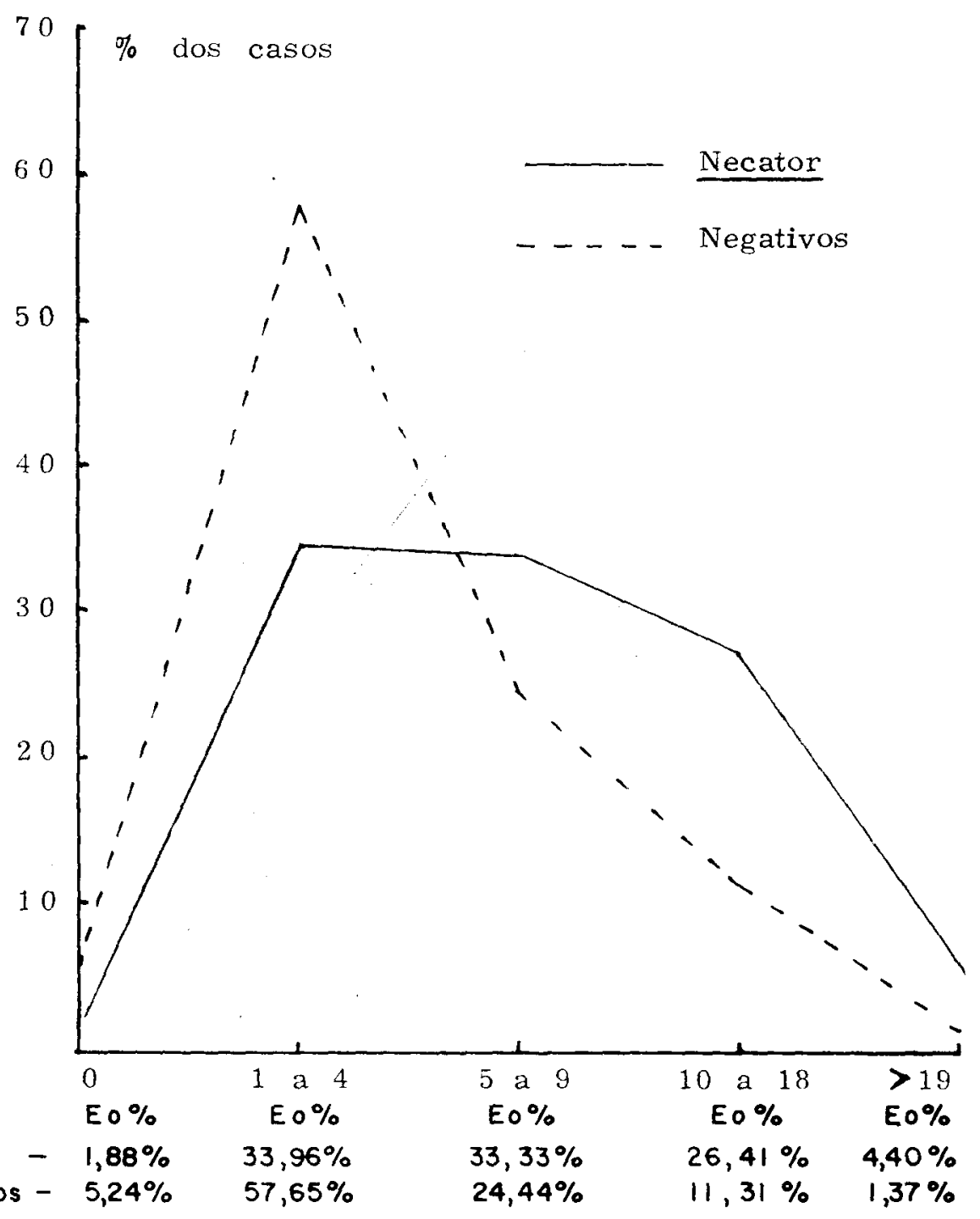


Gráfico 5 Tabela V

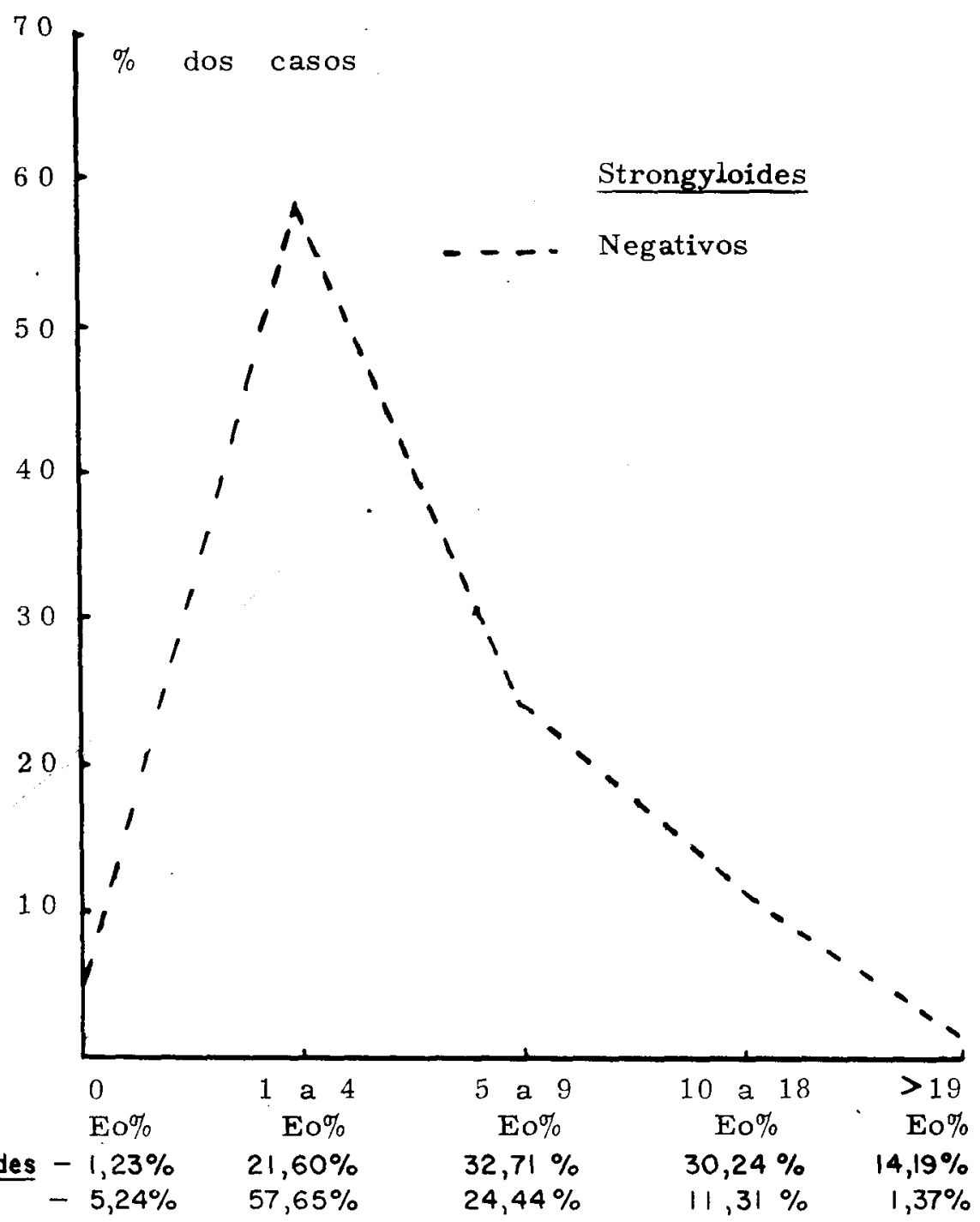


Gráfico 6 Tabela V I

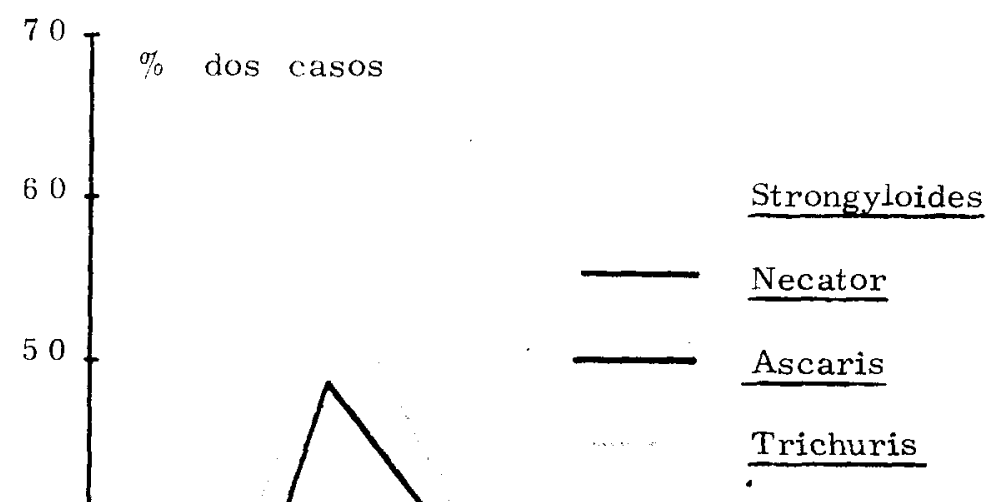

\begin{tabular}{lllllll} 
Strongyloides $-1,23 \%$ & $21,60 \%$ & $32,71 \%$ & $30,24 \%$ & $14,19 \%$ \\
\hline Necator $\ldots \ldots$ & $1,88 \%$ & $33,96 \%$ & $33,33 \%$ & $26,41 \%$ & $4,40 \%$ \\
\hline Ascoris $\ldots \ldots . .4,48 \%$ & $48,07 \%$ & $29,48 \%$ & $15,38 \%$ & $2,56 \%$ \\
\hline Trichuris $\ldots . .4,00 \%$ & $55,65 \%$ & $26,97 \%$ & $12,17 \%$ & $1,21 \%$
\end{tabular}




\section{$\begin{array}{llll}\text { Gráfico } & 7 & \text { Tabela } & \text { VII }\end{array}$}

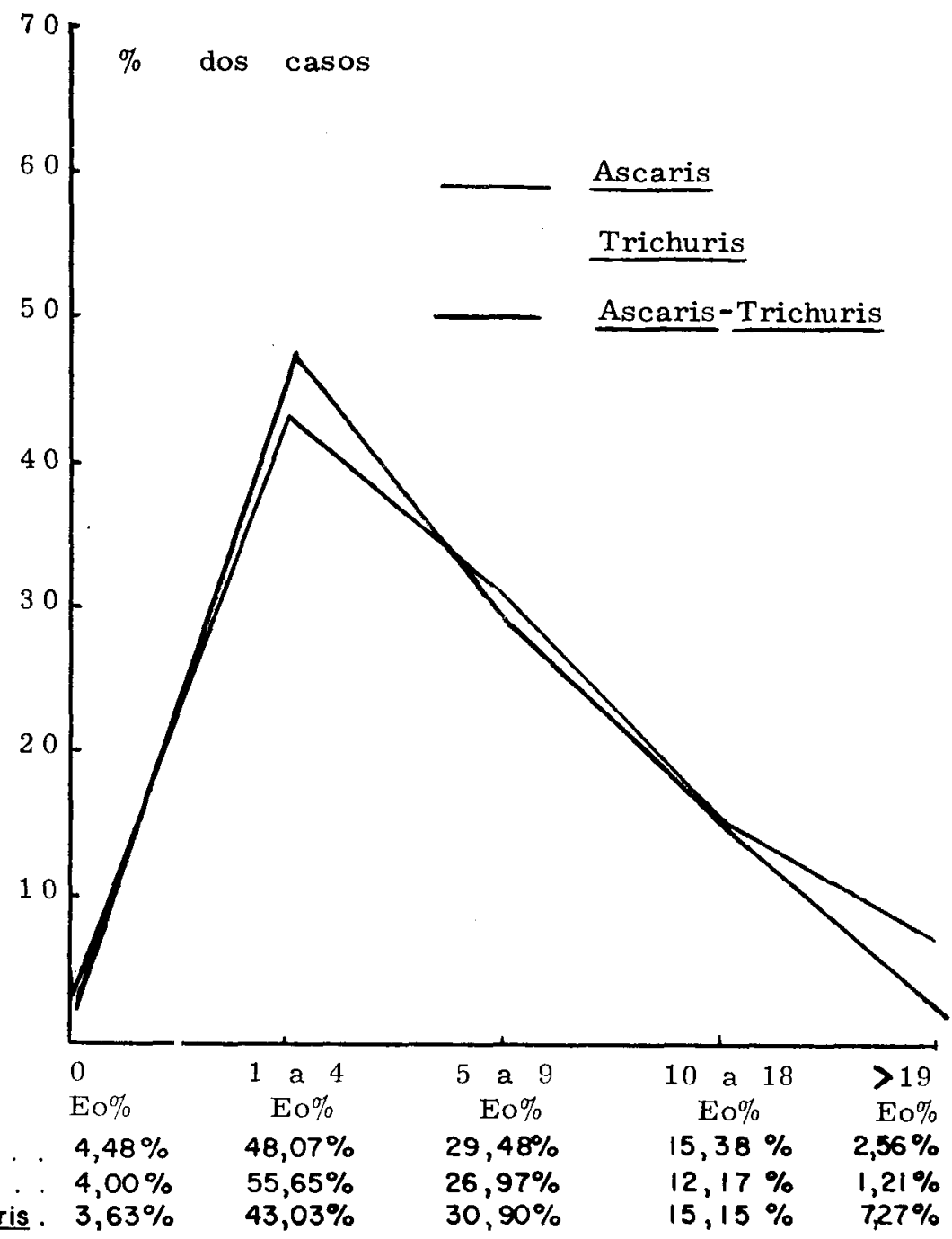


Gráfico 8 Tabela VIII

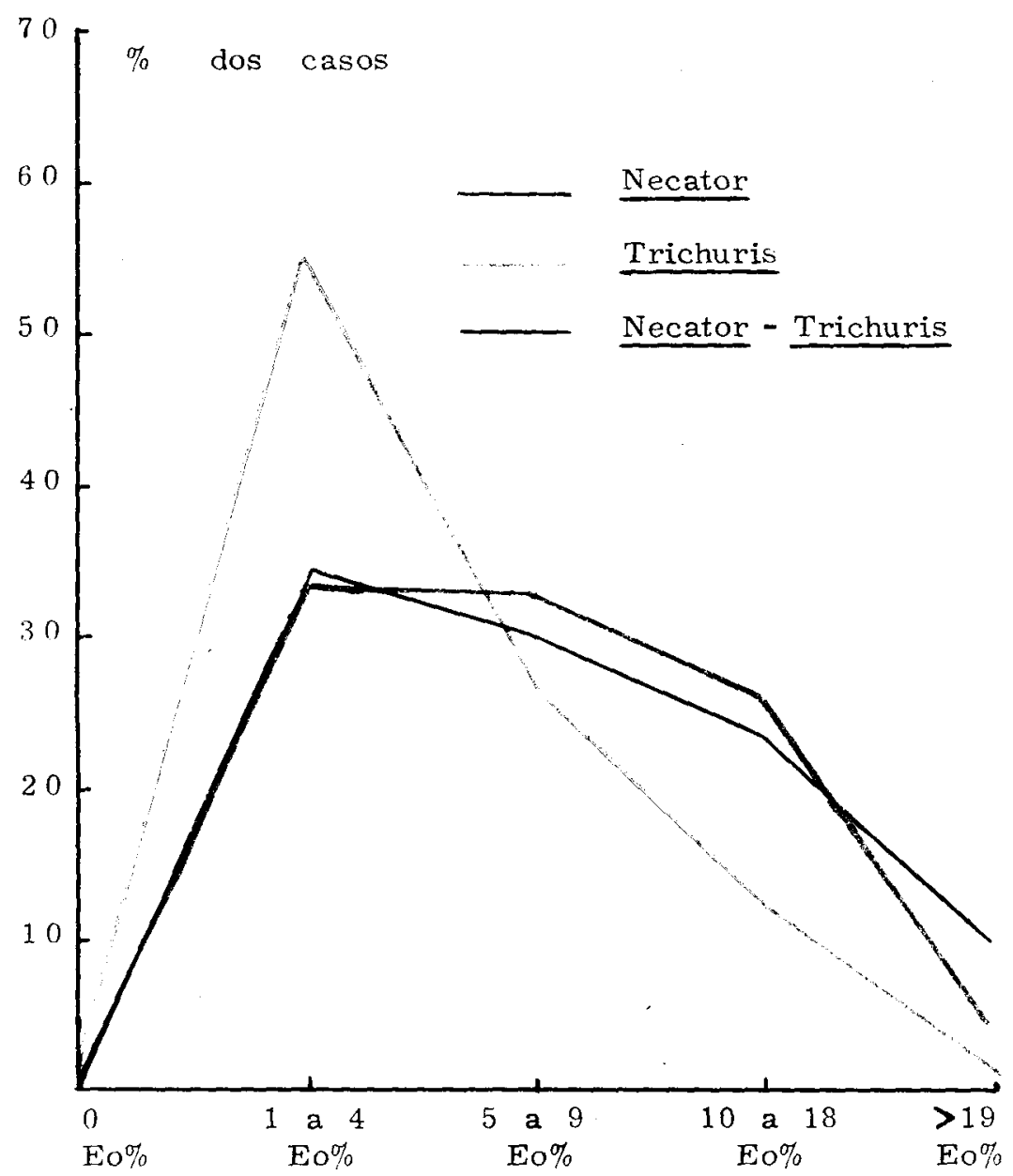

Necotor . . . . . 1,88\% $\quad 33,96 \% \quad 33,33 \% \quad 26,41 \% \quad 4,40 \%$

Trichuris. . . . 4, 4,00\% $\quad 55,65 \% \quad 26,97 \% \quad 12,17 \% \quad 1,21 \%$

Necotor-Trichuris . $1,62 \% \quad 34,95 \% \quad 30,08 \% \quad 23,57 \% \quad 9,75 \%$ 
Gráfico 9 Tabela IX

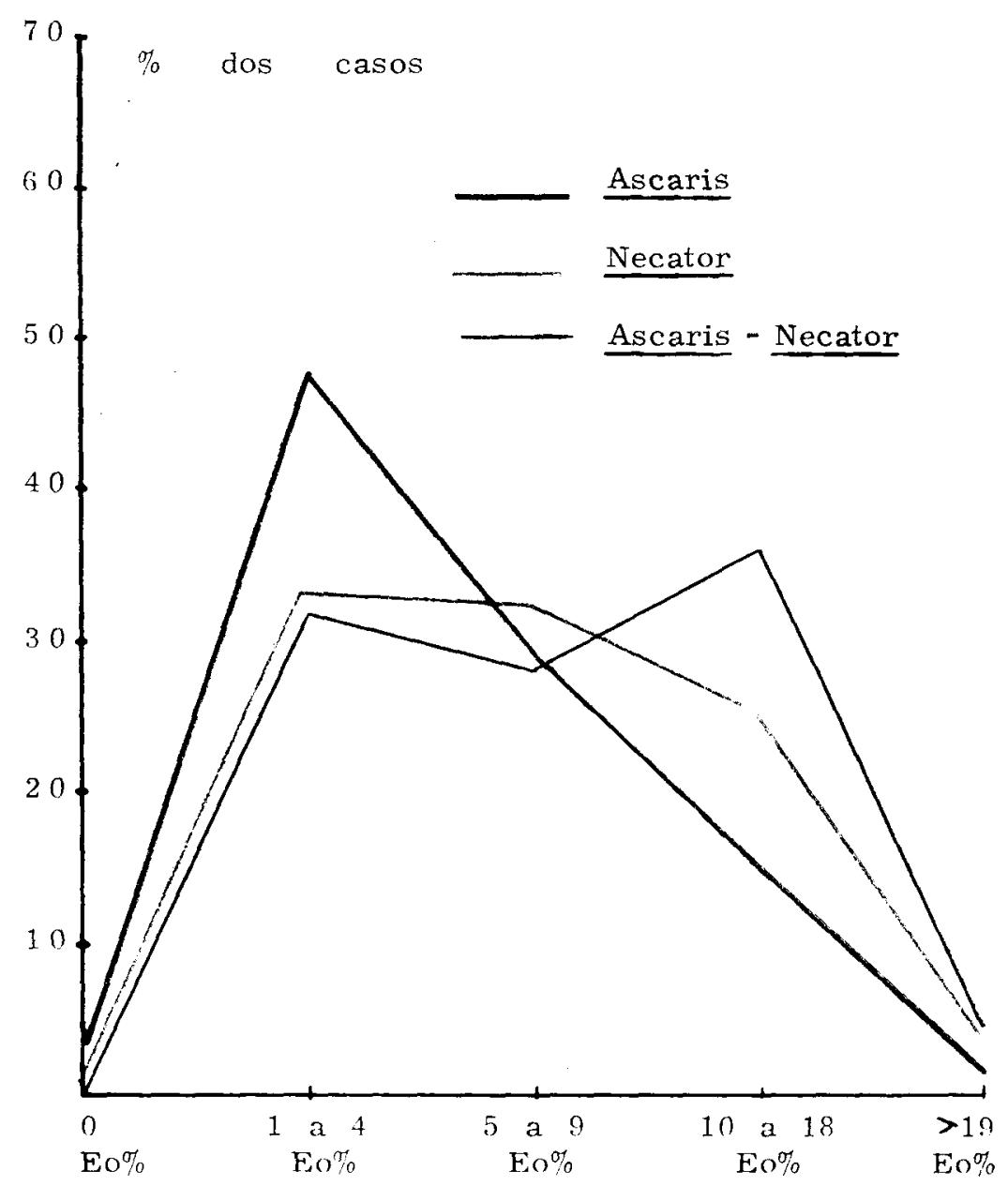

\begin{tabular}{lcccccc} 
Ascoris & $4,48 \%$ & $48,07 \%$ & $29,48 \%$ & $15,38 \%$ & $2,56 \%$ \\
\hline Necotor &. & $4,88 \%$ & $33,96 \%$ & $33,33 \%$ & $26,41 \%$ & $4,40 \%$ \\
\hline Ascaris-Necator . . . & 0 & $32,00 \%$ & $28,00 \%$ & $36,00 \%$ & $4,00 \%$
\end{tabular}




$$
\text { Gráfico } 10 \text { Tabela X }
$$

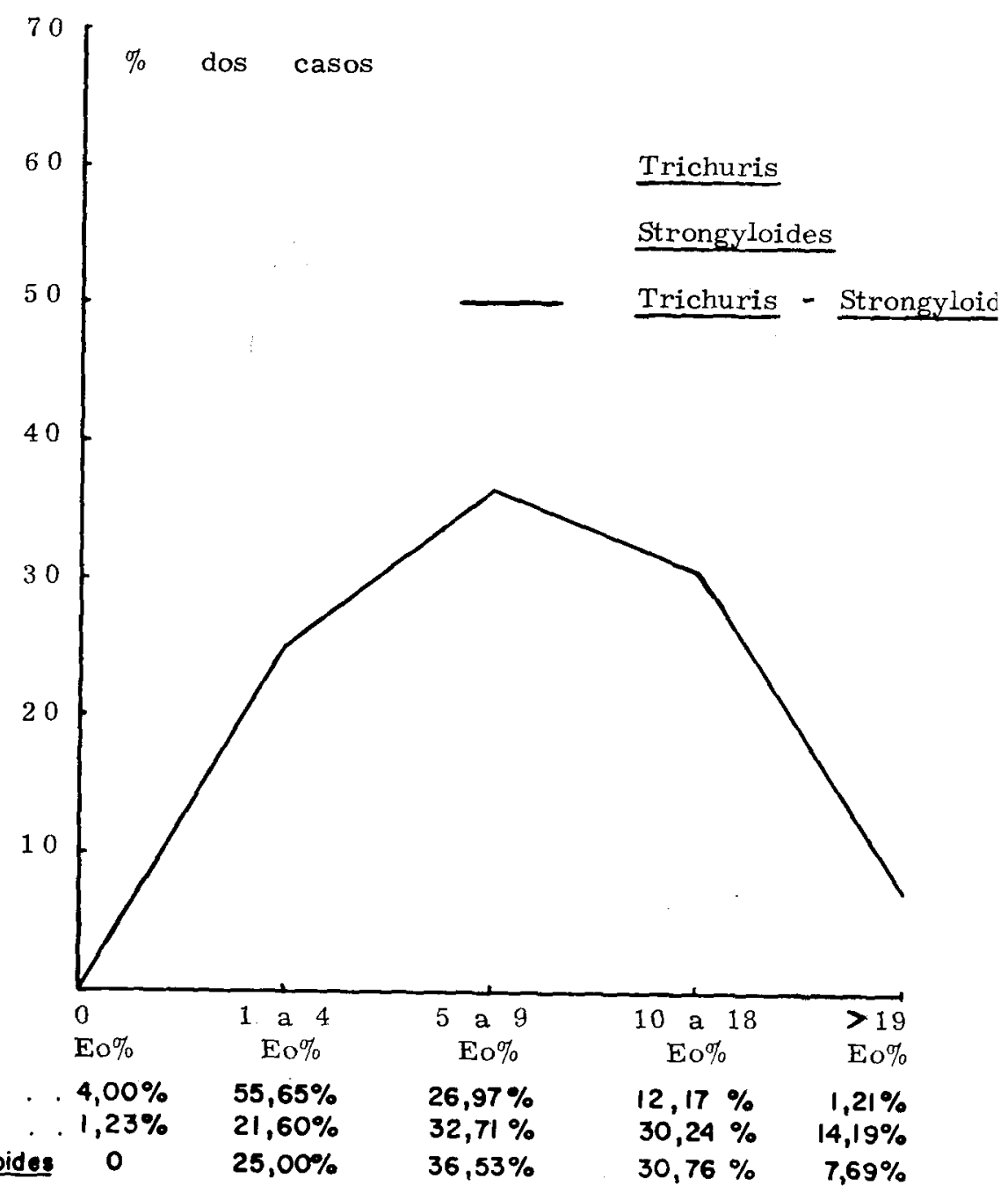


Gráfico $11 \quad$ Tabela XI

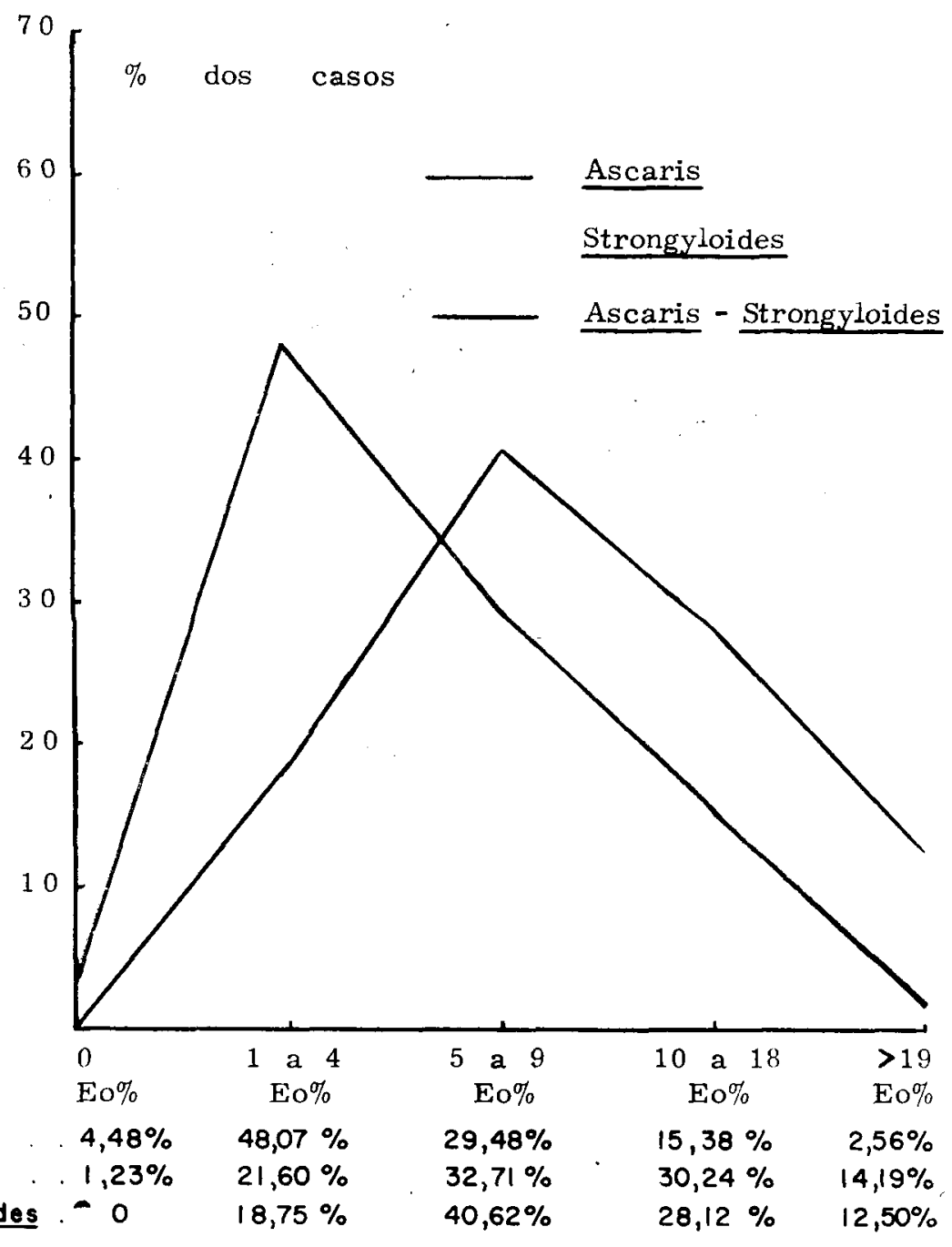


Gráfico $12 \quad$ Tabela XII

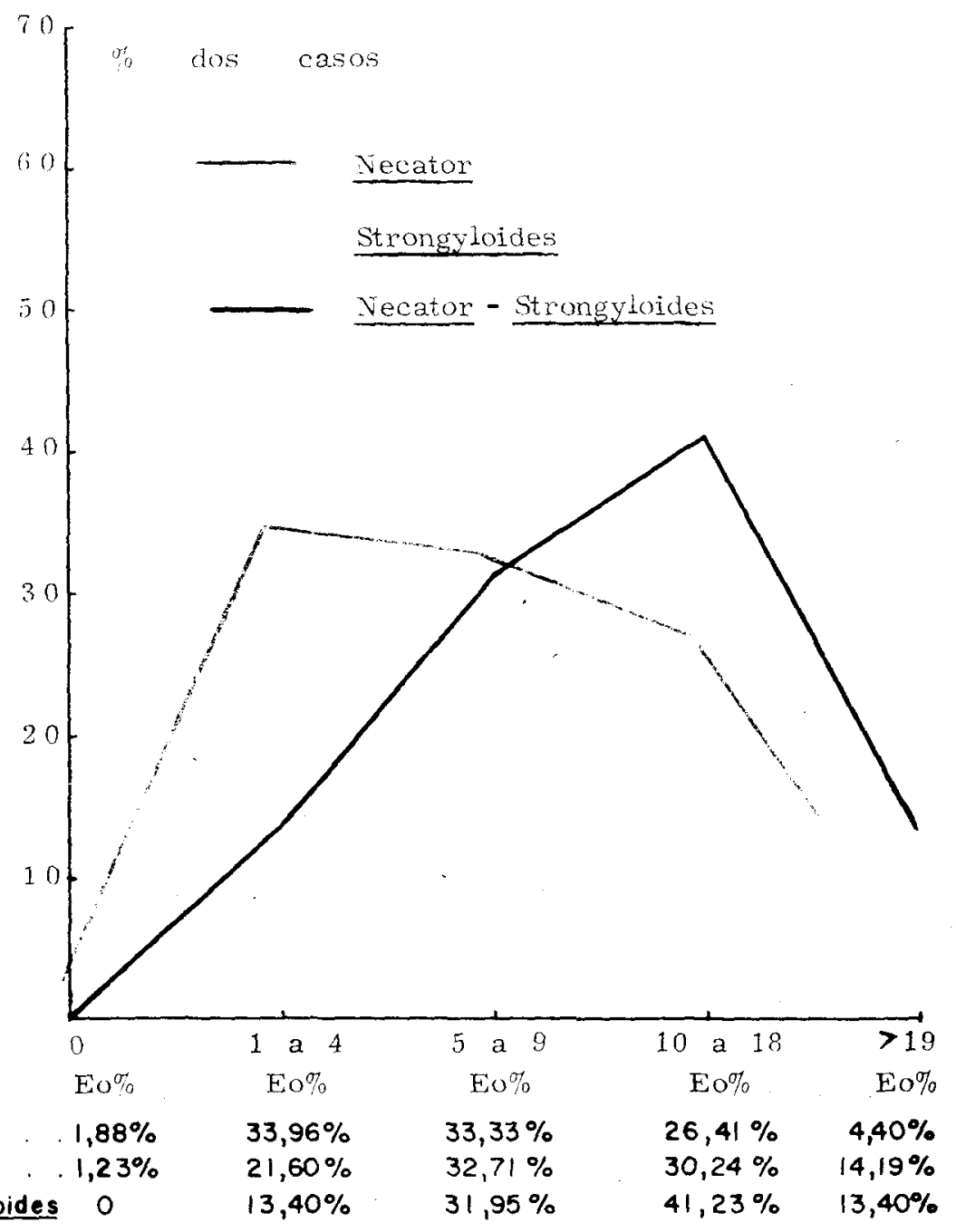


HIPEREOSINOFILIA NAS INFESTAÇŌES POR 4 NEMATÓDEOS

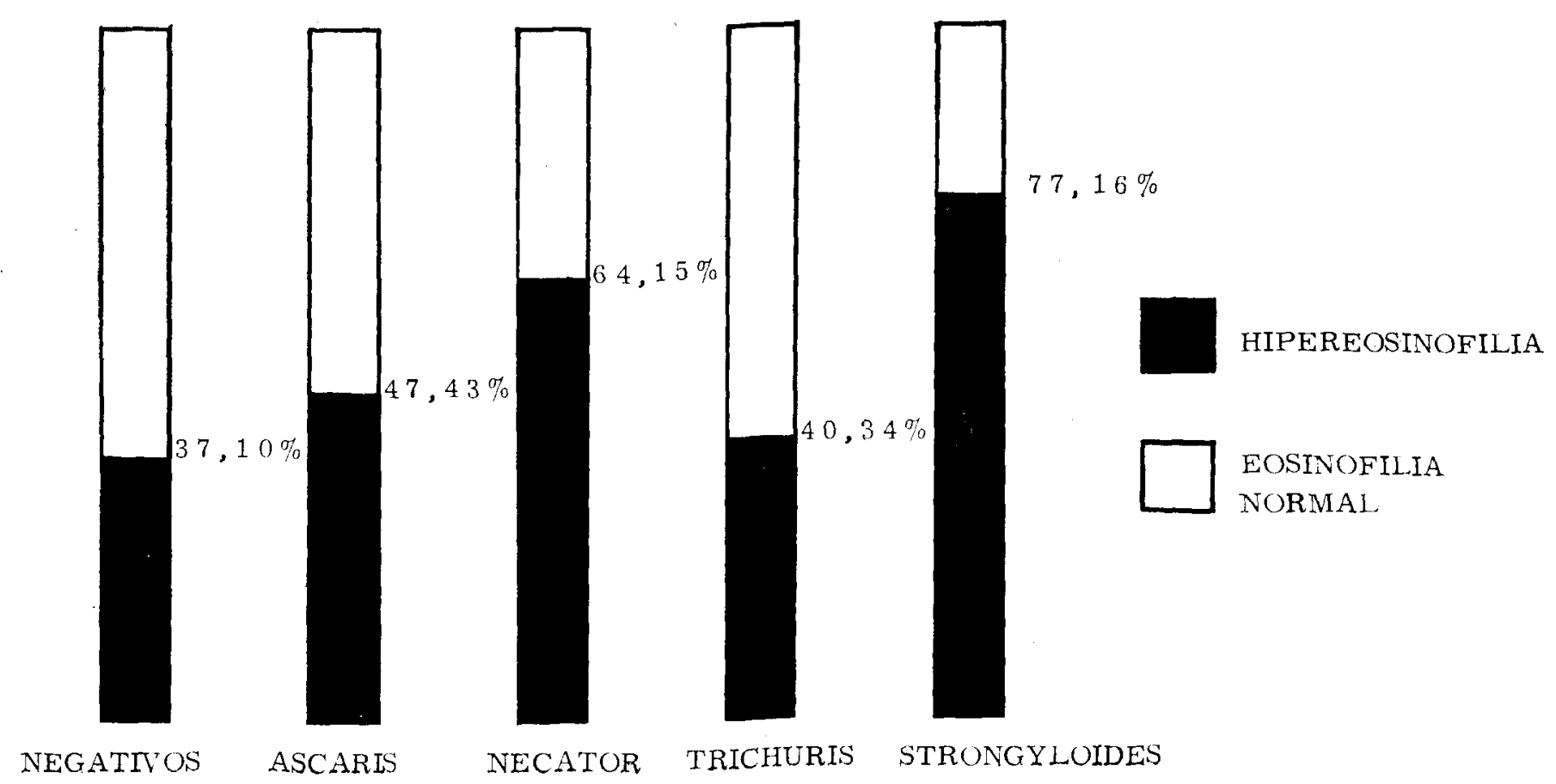


não se beneficiaram com o tratamento, conservadas as suas situações antinômicas, não houve alteração na taxa de eosinófilos.

E interessante considerar que, de quatro doentes observados por êsse pesquisador, dois dos quals com aneosinofilia, ao se curarem passaram a ter eosinofilia normal e os dois outros que não se curaram continuaram com aneosinofilia.

As hipóteses de Arantes Pereira (1) para explicar a existência de hiperleucocitose e abaixamento da taxa dos eosinófilos, são válidas para os casos em que se associa um processo infeccioso, enquanto para os casos com leucocitose normal ou leucopenia, a explicação, a nosso ver, teria por fundamento o esgotamento dos mastócitos e a inatividade da medula óssea.

Outra explicação para a ocorrência do decréscimo dos eosinófilos no sangue em casos graves de estrongiloidose é a carência protêica, tal como se depreende dos estudos de Aschkenasy (1) e das pesquisas clínico-patológicas de Machado da Silva (35).

E possível que as lesões intestinais pro. duzidas pelo strongyloides stercoralis no homem prejudiquem a degradação das proteinas alimentares paralisando o afluxo dos eosinófilos para a parede intestinal e trazendo em conseqüência o desestímulo da medula óssea para a formação de eosinófilos de que resultaria finalmente a eosinopenia parcial ou absoluta.

A hipótese de Arantes Pereira de esgotamento da eosinopoiese da meaula óssea no curso da estrongiloidose poderia ter se fundamentado nos resultados experimentais de Deschiens e Poirier, citados anteriormente, pelos quais se admitira que as lesões das cápsulas supra-renais trariam a depleção dos corticosteróides, resultando de início uma hiperatividade da eosinopoeise que seria substituída posteriormente pela fadiga da medula óssea isoladamente, ou associada à redução dos mastócitos que são no organismo a fonte principal da histaminogênese ativadora da eosinopoiese.

Em continuação à discussão que vimos fazendo sôbre as eosinopenias nas verminoses, particularizando a estrongiloidose, analisaremos os resultados monográficos de quatro pesquisadores brasileiros.
Em De Paola (13), encontramos em 9 dos seus 10 casos de estrongiloidose, todos estudados em vida e "post-mortem", três com aneosinofilia; um com Eo\% $=1 ; 3$ com Eo\% $=3$; um com Eo\% $=5$ e um com Eo $\%=6$.

A conclusão inđiscutível da análise dêstes 9 casos fatais é que a eosinopenia é freqüente nas formas graves da estrongiloidose e precede a morte na maioria dos casos.

A interpretação dos dados de Machado da Silva, confirma a obtida do trabalho de De Paola, notando-se, entre 14 casos graves de estrongiloidose, 11 óbitos de individuos dos quais em vida, 6 tinham aneosinofilia, 3 tinham Eo $\%=2$, um tinha Eo $\%=5$ e um Eo\% $=7$.

A leitura do trabalho de San Juan (46), do qual o próprio autor por discreção tirou sóbria conclusão, não deixa de ser importante pelo fato de mostrar que 8,7\% dos hemogramas realizados para seus doentes tinham aneosinofilia. Concordamos com San Juan, em parte, convencidos de que o conhecimento da eosinofilia sanguínea, de acôrdo com nossa experiência e a de Arantes Pereira, orientará o diagnóstico quando houver hipereosinofilia $e$ nos conduzirá, nos casos francamente sintomáticos, para um mau prognóstico quando houver aneosinofilia.

Dos estudos sôbre a eosinofilia na estrongiloidose, quem mais encareceu seu valor prático foi Arantes Pereira, tanto no tocante ao diagnóstico, ao prognóstico, como ao critério de cura.

A experiência dêsse autor na avaliação dos dados hematológicos no diagnóstico das helmintoses foi confirmada por nós com a observação de 20 individuos de um total de 40 (Tabelas $\mathrm{K}$ e $\mathrm{L}$ ) com hipereosinofilia sanguínea, nos quais a repetição dos exames coprológicos. foi positiva para larvas do Strongyloides. Em vários outros casos igualmente com hipereosinofilia foi possível, em sucessivas repetiçóes dos exames de fezes, evidenciar o parasitismo por Schistosoma mansoni.

Para o estabelecimento do critério de cura da estrongiloidose, a negativação dos exames de fezes para larvas do parasito e concomitante normalização da eosinofilia, tanto nos casos de hipereosinofilia quanto nos de eosinopenia constituem, na ausência de doenças intercorrentes eosinofilogê- 
nicas ou eosinopeniantes, o único recurso válido.

Em tópicos anteriores aduzimos complementarmente às hipóteses de Arantes Pereira algumas proposições que, a nosso ver, facilitam a interpretação da eosinopenia nos casos graves de estrongiloidose, a qual pode ser estendida a outras helminioses, como a esquistossomose.

\section{AGRADECIMENTOS}

Ao terminar êste trabalho agradeço ao Dr. Márcio Rodrigues da Cunha, Chefe do Serviço Médico da Fábrica de Borracha Sintética da Petrobrás e ao Dr. Marcos dos Santos Paiva, Chefe do Serviço Médico da Fábrica Sidney Ross Co., nesta cidade, a confiança a mim dispensada, enviando-me para exames os operários e funcionários daqueles estabelecimentos industriais, demonstrando nessa providência seu elevado espírito de solidariedade humana e cooperação científica. Agradeçc ao colaborador, Dr. José Freitas de Moraes, meu irmão, sua contínua ajuda na execução de grande parte dos 2.666 hemogramas num exaustivo trabalho de pa- ciência para vencer a monotonia das contagens hematológicas, dentro do maior rigor técnico; agradeço aos meus assistentes, Dra. Lúcia de Moraes Fagundes, minha filha, e Dr. Dimas França Ribeiro, a prestimosa colaboração, não só na parte hematológica e parasitológica desta investigação, como principalmente na execução de inúmeras determinações bioquímicas em trabalho paralelo a êste, cujos dados não foram aqui aproveitados; agradeço à Sra. Vicentina Fernandes Marathona, dedicada técnica em parasitologia, seu solicito e prestimoso auxílio na manipulação de .... 10.664 exames de fezes (4 para cada um dos 2.666 casos); agradeço à assistente da Cadeira de Parasitologia da Faculdade de Farmácia da U.F.R.J., Dra. Wanda Keller da Silva, e Dra. Marluis Martins, da Universidade do Rio Grande do Norte, estagiária na Cadeira de Parasitologia da Faculdade de Farmácia da UF.R.J., a colaboração no levantamento bibilográfico necessário a êste trabalho. Finalmente agradeço ao Professor Enio Garcia Goulart, sua inestimável assistência, oferecendo sugestões e fazendo precioso estudo crítico na leitura do manuscrito.

\section{$S U M M A R Y$}

1 - The stools of 2.666 individuals were examined (workers and officeholders of two industrial companies located in the states of Guanabara and Rio de Janeiro, Brasil);

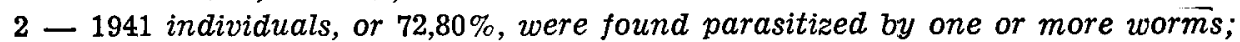
the stools of the remaining $725(27,20 \%)$ yielded negative results;

3 - A complete hemogram was made of each of the 2.666 individuals; the eosinophiles rate was used - the use of this rate, in association "with stool examinations, being the main object of this work;

4 - Table A shows how many times each worm was observed, and also the percentages. Despite the non-epidemiological character of this work, it was found that $46,81 \%$ were infested by Trichuris trichiura; $23,85 \%$ by Strongyloides stercoralis; $22,46 \%$ by Necator americanus and/or Ancylostoma duodenale; $20,51 \%$ by Ascaris lumbricoides; $1,65 \%$ by Schistosoma mansoni; $0,67 \%$ by Enterobius vermicularis; $0,26 \%$ by Taenia solium or $\mathrm{T}$. saginata; and $0,11 \%$ by Hymenolepis nana;

5 - Stool examinations were carried out by the methods of Faust (or Ritchie), Willis, Baermann and sedimentation;

6 - Reiative or percent values of eosinophilia were recorded, a rate of $5 \%$ or higher being considered as hypereosinophilia (Eo $>5 \%)$;

7 - Factors which give rise to oscillations in normal eosinophitia, such as age, race, hours of the nycthemer, physical factors, sex, chemical factors, and others, were concisely considered;

8 - A fuller treatment was given to the differences between parasitic and non-parasitic hypereosoniphilia, with emphasis on the dynamics of eosinophilia as given by the Lavier curve; 
9 - The 2.666 cases were distributed according to the different degrees of eosinophilia. Graphs and curves were drawn showing the distribution of each worm and its associations;

10 - In order to properly explain the subject, an eosinophilic index was set up. This index is defined as the ratio between the number of cases with Eo $>5 \%$ in a given group, and the number of cases in the same group with Eo $<5 \%$. The total number of positive cases yields the "a"erage eosinophilic index", while the total number of negative cases yields the "residual eosinophilic index"

11 - By estabiishing the eosinophilic index it is possible to evaluate the eosinophilogenic capacity of each isolated worm and its associations;

12 - Special attention was given to the problems raised by the existence of hypereosinophilia in cases of negative coprological test for worms; several biological features of the subject were reviewed;

13 - Another question of great clinical importance explained in this work is that of the occurence of cases of parasitism by worms, without hypereosinophilia. The author, based on data of his own and on other data taken from the literature on the subject, discusses the physiopathology of eosinopoiesis in helminthiases and puts forward an interpretation for this as yet not fully explained fact.

\section{BIBLIOGRAFIA}

1 - ARANTES PEREIRA, O. - Estrongiloidose. O Hospital, 66: 157-195 e 66: 381-424, 1964 .

2 - ASCHKENASY, A. - Le rôle des hormones dans la regulation de l'éosinophilie sanguine. Le Sang, 28 (5) : 400-485, 1957.

3 - BACCHI NAVEIRA, J. - Aspectos da Biologia dos eosinófilos. Rev. Bras. Malariologia e D. Tropicais, 12 (1): 103-118, 1960.

4 - BEAVER P.C. \& DANARAJ, T.J. - Pulmonary Ascaris Resembling Eosinophilic Lung Autopsy report with description of larvae in the bronchioles. Am. J. Trop. Med. and Hyg., 7: 100-111, 1958.

5 - BINET, L. \& MATHÉ, G. - Étude d'éosinophilie physiologique des sujets âgés. Press med., 59; 305-307, 1951.

6 - BLANC, F. \& NCSNY, Y. - Evolution de nos connaissances eri matiére d'éosinophilie tropicale et position actuelle lu probleme. Bull. Soc. Path. Exot., 55 (4) : 695, 1962.

7 - BONNIN, H. \& MORETTI, G.F. Lois d'occurrence de l'éosinophilie dans les parasitoses animales. La Press Med. 60 (11) : 221-222, 1952.

8 - CALLOT, J. \& HELLUY, J. - Parasitologie Medicale. Editions Medicales Flamarion, Paris. 1 vol., 1-645, 1958.

9 - CARVALHO, AZARIAS DE ANDRADE - Ancilostomose in Veronesi Doenças Infecciosas e Parasitárias. Ed. Guanabara Koogan S.A., Rio de Janeiro, 1 vol. 1-924, 1962.

10 - CHaIA, G. - Contribuição para o estudo da reação intradérmica com antígeno do Strongyloides ratti (Sandground, 1925) no diagnóstico da estrongiloidose humana. Instituto de Endemias Rurais - Belo Horizonte. Tese, 1962 .

11 - COSTE, $\mathrm{F}$. \& COLS. - Comment agit le salicylate de sodium? Presse Méd. 61: 979, 1953.

12 - COSTA, ORIANDG \& COLS. - Eosinofilia sanguínea: aspectos observados no parasitismo intestinal. Rev. Serv. Especial Saúde Pública, 11 (1) : 197-205, 1960.

13 - DE PAOLA, D. - Patologia da Estrongiloidose. Bol. Centro Estudos do Hosp. IPASE., 14 (1-2): 3-98, 1962 .

i4 - DEANE, MARIA P. - HeImintos eliminqdos por um grupo de residentes na Amazonia. abós ư tratamento pelo hexilresorcinol. Rev. Sev. Espe a Sa de Pública, 3 (2): ..... 443-464, 1950.

15 - DESCHIENS, RCBERT - Etude comparée des hypereosinofilies parasitaires et non parasitaires. Bull. Soc. Path. Exot. 55 (4): 529-545, 106 ?

16 - DESCHIENS, R. \& BENEX, J L'éosinophilie sanguine physiologique et juxta-physiologique. Bull. Soc. Path. xot. 55 (4): 529-545, 1962.

17 - DESCHIENS, R. \& POIRIER, M. - L'immunité dans les infestations parasitaires. Ann. Inst. Pasteur, 83: 725-744, 1952 .

18 - DESCHIENS, R. ET POIRIER, M. - Action éosinophilogéne et toxique du piment rouge chez le cobaye. 
C.R. Soc. Biol. (Paris), 147: ... 1021-1023, 1953

19 - DESCHIENS, $R$. \& PCIRIER, $M$ - Etude comparée des propriétés toxiques éosinophilogénes de differents extraits de douve chez le cobaye. C.R. Soc. Biol. (Paris), 147: 1059-1061, 1953 .

20 - DESCHIENS, R., POIRIER, M. \& LAMY, L. - Les alterations anatomo-pathologiques de la surrénale dans l'éosinophilie experimental du cobaye. Bull. Soc. Path. Exot. 46: 954-955, 1953.

21 - FAUST, E.C. - Experimental studies on Iruman andprimate species of Strongyfoides. II - The development of Strongyloides in The experimental host. Am. J. Hyg. 18: 114-132, 1933

22 - F"ERNEX, MICHEL - Eosinoplilie et Mastocytose-Physiologie des hiperéosinophilies. Étude expérimentale et clinique. Bull. Soc. Path Exot. 55 (4): 508-529, 1962.

23 - GAUBERT, J., CLAVERIE, P. \& GAUBERT, MME. J. - Intérêt de l'éosinophilie sanguíne chez le nourrisson et l'enfant. Press Med., 68: 265-267, 1960.

24 - GOULART-E.G. - Diagnóstico-tratamento da enterobiose. Rev. Bras med., 16 (11): 756-760, 1959 .

25 - GOULART, E.G.. KELLER DA SILVA, W.R., MARTINS, M.S.B. \& MORAES, D.S. - Positividade e negatividade nos exames coproscópicos de portadores de enteroparasitos. Rev. Bras. Med., 24 (9) : 720-724, 1967.

26 - HALPERN, B.N., DOMINÉ, E. \& FRAY, A. - Le role des mediateurs chimiques dans la regulation de l'éo. sinophilie sanguine. Bull. Soc Path. Exot. 55 (4): 489-499, 1962.

27 - HARANT, H. - La notion d'impasse en parasitologie: son incidence dans les éosinophilies tissulaires. Bull, Soc. Path. Exot., 55 (4) : . $576-588,1962$.

28 - HSU, H. F, \& CHOW, C. Y. Studies on human intestinal helminths in 809 autopsy cases. Bul. Fan. Mem. Inst. Biol. 8: 245, 1938. in Stitt's Diagnosis, Prevention and Treatment of Tropical Diseases. The Blakiston Company. Pa. U.S.A. Volume II - 872-1747, 1943.

29 - JUNG, R.C. AND JELLIFFE, D.B. - Intestinal helminth. In Trowell, H.C. and Jelliffe, D.B. Diseases of Children. Arnold (Publishers) Ltda. London.

30 - KLOPSTOCK \& STEINITZ - In Mansons Tropical Diseases. Cassel-London, 15 th Ed. 1964.

31 - LAPTEV, A.A. - Clinical observations on strongyloidiasis of the lung. Klinicheskaya Meditsima, 23 (3):
75-76, 1945 in Helminthological obs. 14: $61-167,1946$.

32 - LAVIER, G. - L'éosinophilie sanguine dans les helminthiases. Le Sang. 16: 510-528, 1944-1945.

33 - LAVIER, G. - Les éosinophilies parasitáires. Le Sang. 28: 468-479, 1957.

34 - LUTZ, ADOLPHO - O Schistosoma mansoni, segundo observações feitas no Brasil (The Schistosomum mansoni and Schistosomiasis in Brazil). Mem. Inst. G. Cruz, ... 11: $109-140$ e 1:2-155, 1919.

35 - MACHADO DA SILVA, RUY - Estrongiloidíase, Rev. Brasil. Malario$161-738,1966$

36 - MANN, A. \& LEHMANN - The eosinophil level in psychiatric conditions. In Deschiens et Benex - op. cit. Canadian Med. Ass. J., 66 : 52, 1952, in Deschiens et Benex, op. cit.

37 - MEIRA, JOÃO ALVES - Esquistossomose mansônica in Veronesi, $\mathbf{R}$. - Doenças Infecciosas e Parasitárias. Ed. Guanabara Koogan S.A., Rio de Janeiro, 1 vol. 1-924, 1962.

38 - MEIRA, J.A. \& GALVÄO, A.L. AYROSA - Considerações sôbre a fase larvaria da infeccão ancilostomótica Sîbre dois casos clínicos de ancilostomiase aguda. Arq. Fac. Hig. Saúde Pública; 3: 29, 1949.

39 - MORAES, R.G. - Determinação do espetro parasitário intestinal. O Hosnital. 66 (4): 735-745, 1964.

40 - MORVAN, M.M. VOIwARD, F. \& BAISE - Le parasitisme intestinal des malgaches (Parasitologie, Hemathologie). Bull. Soc. Path. Exot. 21 (1): 20-25, 1928

41 - NEVEU LEMAIRE. M. - Traité d'Entomologie medicale et veterinaire. Vigot Freres, Ed. Paris. 1 vol. 1-1339, 1938.

42 - PESSOA. S.B. - Parasitologia Médica. Ed. Guanabara Koogan S.A., Rio de Janeiro, 1 vol. 1967.

43 - PESSOA, S.B. \& MEIRA, J.A. A eosinofilia sanguínea. Soc. Ed. Med. Ltda. Sâo Paulo, 1 vol. 1935.

44 - RILEY. J.F. - The mechanisme of histamine release from mast cells. J. Pharm and Pharmacology, 10: 271, 1958.

45 - RILEY, J.F. - The mast cells. E. and $\mathbf{S}$. Livingstone Ltda. Edinburgh and London. 1 vol. 1959.

46 - SAN JUAN, F. - Contribuição ao estudo da estrongiloidose. O Hospital. 61: 219-244, 1962.

47 - SCHNEIDER, J. - L'éosinophilie Tropical n'est pas une maladie. Bull. Soc. Path. Exot., 55 (4): 695-967, 1962.

48 - VAN DER SAR, A. - Sur l'étiologie de l'éosinophilie tropicale a Curaçao. Bull. Soc. Path. Exot. 55 (4) : ... 646-655, 1962. 
49 - VIANNA MARTINS, A. - Diagnóstico de laboratório da esquistosomose mansoni. Tese - Fac. Medicina da Universidade de Minas Gerais. 1 vol. 1949.

50 - WEINBERG, M. \& SEGUIN, P. Recherches biologiques sur l'éosinophilie. Ann. Inst. Pasteur, 28: .... 470-508, 1914.

51 - WINTROBE, MAXWELL M. - CliRecherches biologiques sur l'éosinophilie. Proprietés phagocytaires et absorption de produits vermineux.
Ann. Inst. Pasteur, 29: 323-346, 1915.

52 - WINTROB, MAXWELL M. - Clinical Hematology. Lea \& Febiger. Pa. U.S.A. 1 vol. 1-1185, 1953.

53 - YOKOGAWA, S. \& WAKESHIMA, T. - On fecal examination for parasites of School Children of Biological Observations on Ascaris lumbricoides. J. Med. Assoc. Formosa, 31: 552-570, 650-682, 1932 in Craig and Faust's Clinical Parasitology. 7th Ed. Lea \& Febiger; 1964. 